\title{
Consagración de lo diverso. Una lectura de la poesía peruana de los noventa
}

\author{
Luis Fernando Chueca
}

\section{Cero}

Hablar de poesía de los noventa supone considerar una secuencia (cincuenta, sesenta, setenta, ochenta, noventa, como estancos separables) cuya validez responde fundamentalmente a la visión e intereses de los propios implicados en la producción de los discursos poéticos. Pocas veces se ha planteado una revisión de la poesía peruana del siglo XX que atienda, no tanto las necesidades de protagonismo "generacional", sino el proceso como conjunto. Una revisión, digamos, pensada como una lectura de conjunto desde el siglo XXI hacia el siglo que se acaba de cerrar. Desde esta perspectiva resultaría inconveniente mantener las divisiones decenales, pues la poesía, creo que es ya una verdad, aunque amarga para muchos, no cambia radicalmente cada diez años, y el proceso debe verse como tal, con sus cambios y rupturas, es cierto, pero también con sus continuidades, que suelen ser más.

No es esto, sin embargo, lo que pretendo con el presente trabajo. La nueva revisión -en la línea de lo que Alberto Escobar, en su célebre 
Antología de la poesía peruana, quizás el intento más serio de comprender la tradición poética contemporánea de nuestro país, adelantaba en 19731 - queda anotada como tarea. Lo que busco (aunque el título puede provocar varias lecturas), es una aproximación a la hornada de poetas jóvenes aparecidos alrededor de $1990^{2}$ en el Perú; aunque decir "Perú" encierra una pretensión que no estoy en condiciones de cumplir. Otro problema de nuestra crítica literaria, de nuestra industria (digo, es un decir, parafraseando a Vallejo) editorial, de nuestro periodismo cultural, de nuestras comunicaciones: el panorama que plantearé corresponde fundamentalmente a lo que ocurre en Lima o, en todo caso, a lo que pasa o ha pasado por Lima3.

¿Qué es, luego de esta introducción, lo que caracteriza a los poetas peruanos de los noventa? ¿Qué podemos decir que tenga validez para, por citar algunos poetas entre los más jóvenes, los casos de la densa poesía del conocimiento, la revelación y el cuerpo de Alberto Valdivia, la etérea voz de Bili Sánchez o el malditismo autoirónico de Lizardo Cruzado? ¿O, si miramos entre los mayores de la década, para los sonetos de Lorenzo Helguero, la dicción conversacional de los primeros libros de Alonso Rabí, el nihilismo de Montserrat Álvarez, la reivindicación

1 Antología de la poesía peruana. Dos tomos. 2. edición. Lima: Peisa, 1973. La primera edición, en un solo tomo, la publicó en 1965 la editorial Nuevo Mundo.

2 De hecho, varios de los mencionados en este texto publicaron sus primeros poemas -en revistas, por lo general- desde 1986 o 1987, pero comienzan a ser reconocidos en el espacio literario joven recién a partir de 1990.

3 Es un punto contra el que, justificadamente, arremete el manifiesto "A los poetas que vendrán", firmado por los jóvenes Antonio Sarmiento y Ricardo Ayllón (2000). Lamentablemente no es posible para mí (e imagino que no estoy solo en esta imposibilidad) abarcar, como debería, un espectro geográfico más completo. Tampoco, es obvio, he logrado conocer todos los poemarios publicados por los poetas de los noventa (sin contar lo aparecido en revistas, que también debería ser considerado, pues forma parte del corpus de esta década; pero que dejo de lado en el presente trabajo). El poeta Alberto Valdivia me alcanzó, cuando revisaba este artículo para su publicación, un listado elaborado por él con más de ochenta poetas que comenzaron a publicar en los noventa. Varios de ellos, por cierto, me resultaban absolutamente desconocidos, y sus libros, inhallables. Creo, sin embargo, que -a pesar de las graves omisiones en que pueda estar incurriendo- lo leído (que se anota en la bibliografía que acompaña al texto) me permite hacer planteamientos con cierta seguridad. 
del espacio familiar de Gastón Agurto o la fragmentación de la voz de Las quebradas experiencias de Xavier Echarri?

\section{Uno}

La variedad de las menciones anteriores basta para iniciar la revisión con una pregunta: ise puede, como se ha pretendido, hablar de una "generación de los noventa" en la poesía peruana? Los años iniciales de la década fueron testigos de los primeros fuegos (artificiales) que anunciaban el nacimiento de una nueva generación. Se estaba, así, inventando, como es ya costumbre en nuestra tradición reciente, un nuevo colectivo, algunos de cuyos integrantes lucían orgullosos el rótulo, sin tomar en cuenta que, apenas iniciada la década y casi sin libros en su haber, era bastante prematuro plantear la incipiente obra de los poetas que por esos años comenzaban a hacer públicos sus textos como una "propuesta generacional".

Además, esta práctica periodificadora, que, como sabemos, se ha aplicado entre nosotros religiosamente (mas no rigurosamente) desde los años cincuenta, ha representado un abuso del paradigma generacional propuesto por José Ortega y Gasset y no contribuye en nada a una mayor comprensión del fenómeno literario peruano ${ }^{4}$; invita, sí, a una identificación simplificada (casi caricaturizante) de los procesos y actores de nuestra literatura. Una aplicación del método generacional debería realizarse con todo rigor o no realizarse. Y quizá, extremando el argumento, sea necesario descartar definitivamente el método generacional pues, a pesar de lo que observa el propio Ortega en cuanto a que "dentro de ese marco de identidad [generacional] pueden ser los individuos del más diverso temple ${ }^{\prime \prime}$, a través del término, tal como

4 Un detalle, como muestra: se soslaya, en nuestro uso del modelo organizador, la idea de que las generaciones no pueden ser sólo literarias -y menos exclusivamente poéticas-: la generación "es como un nuevo cuerpo social íntegro, con su minoría selecta y su muchedumbre, que ha sido lanzado sobre el ámbito de la existencia con una trayectoria vital determinada". Ortega y Gasset, José. El tema de nuestro tiempo. Madrid: Editorial de la Revista de Occidente, 1958, p. 7.

5 Y añade: "hasta el punto de que, habiendo de vivir los unos junto a los otros, a fuer de contemporáneos, se sienten a veces como antagonistas". Ibídem. 
se usa en reseñas, artículos periodísticos, conversaciones e incluso estudios, "se imagina la historia como un proceso unilineal, desestratificado, homogéneo. Como si un conjunto de coincidencias cronológicas [...] pudiera borrar las diferencias sustanciales que existen en un mismo momento entre diversos grupos sociales, las diversas clases que existen en un determinado país...", como escribió Antonio Cornejo Polar ${ }^{6}, \mathrm{o}$, ampliando, diversas posturas ante la vida y el arte y, por ende, propuestas estéticas incluso enfrentadas.

El rótulo generacional, sin embargo, sirvió como mecanismo de identificación y publicidad a los sectores más "activos"7 en los años iniciales de la década para intentar ocupar el espacio literario y marcar la importancia de su presencia dentro de la escena poética local ${ }^{8}$, concitando, con sus recitales, grupos, revistas y libros iniciales, cierto interés de algunos críticos, periodistas y lectores en general, que pronto adoptaron el ligero uso del membrete. Pero la supuesta "generación del noventa" no cumplía (no podía cumplir, como hemos visto) ni con la configuración de un lenguaje generacional ni con posturas homogéneas por parte de sus supuestos miembros. Quizás como nunca, los poetas de los noventa se encuentran en las antípodas de un espíritu generacional. La heterogeneidad de poéticas, posturas creativas y discursos ideológicos (una dispersión monumental) impiden, a pesar de que incluso se haya publicado un libro con tal nombre ${ }^{9}$, el uso del cartel de "generación del noventa".

6 Cornejo Polar, Antonio. "Testimonio de Antonio Cornejo Polar", en Varios autores. La generación del 50 en la literatura peruana del siglo XX. Lima: Universidad Nacional de Educación (UNE), 1989, p. 149.

7 "Activos" en cuanto a actividad pública con vistas a la difusión de la poesía y de la existencia de los poetas.

8 Así lo señala Paolo de Lima, integrante de Neón, uno de los grupos de mayor actividad en los años iniciales de la década: “... para copar ese espacio, para que la gente supiera que existíamos, había que irrumpir con algo. Nosotros habíamos nacido alrededor de 1970. Así, utilizamos un cliché que llamó la atención: nos llamamos la generación del 90". En “No somos escépticos ante la vida", entrevista con el grupo Neón. Revista Arco Crítico 2, junio 1993, p. 23.

9 Santiago Risso, con el sello de la Biblioteca Nacional, publicó La generación del 90 en 1996. 
Lo anterior, sin embargo, no impide considerar la existencia de "promociones" o grupos de poetas (no necesariamente institucionalizados) cuyo vínculo estructurante está dado por cierta cercanía de experiencias, alguna amistad, la coincidencia de su aparición en el espacio literario, la proximidad de edades y algo de afinidad de sus propuestas. Rasgos éstos que, como para el caso de los cincuenta ha señalado el narrador Carlos Eduardo Zavaleta ${ }^{10}$, rigen parcialmente a lo más los años formativos de los escritores $\mathrm{y}$, a medida que avanza el tiempo, se disuelven en otro tipo de afinidades y ligamentos. Se puede observar, por ejemplo, cierta artificialidad innecesaria en los panoramas de la poesía peruana última -que, sin duda, el tiempo se encargará de corregir- en la inclusión, para citar algunos nombres, de Rodrigo Quijano o Jorge Frisancho en un territorio epocal distinto (los ochenta) a, digamos, César Gutiérrez o Xavier Echarri (los noventa). Es cierto, sin duda, que la presencia de Quijano y Frisancho en una antología como La última cena. Poesía peruana actual (Asaltoalcielo/editores, 1987) está de sobra justificada, pues, además de cierta comunidad de experiencias (publicación de sus primeros libros en los sellos Kloaka y Asaltoalcielo, respectivamente; experiencias laborales en común, amistad) con los antologadores y buena parte de los antologados, es obvia su inclusión en un panorama de los ochenta, cuando habían dado ya muestras del valor de su poesía y aún no había terminado la década. La crítica, más bien, quiere cuestionar un modo de organización (que en este trabajo se asume a partir de las observaciones planteadas) que establece una distancia temporal entre autores que publicaron, si bien no sus libros, sí sus primeros poemas en revistas, prácticamente en los mismos años. $Y$ es que, vuelvo sobre ello, filiaciones y proximidades no bastan para construir generaciones.

\section{Dos}

A inicios de la década, grupos, como Neón, Estación 32, Geranio Marginal, Vanaguardia o Noble Katerba ${ }^{11}$-casi una avalancha-,

10 Véase “Delgado, Zavaleta y Ribeyro y la Generación del 50". La Casa de Cartón de Oxy 5, Segunda época. Lima, primavera-verano, 1994, p. 4.

11 Véase el artículo "Con-versación de - vida. Nuevos grupos de poesía en Lima". Imaginario del arte 4, diciembre 1992, pp. 4-6. 
trataron de reeditar algunas de las estrategias de apropiación del espacio literario (recitales, revistas, presentaciones conjuntas, declaraciones) emprendidas en décadas anteriores por Estación Reunida, Hora Zero, La Sagrada Familia, Kloaka u Ómnibus. Esta actitud, sin embargo, desde la ruidosa disolución de Kloaka en los ochenta, enfrentaba una inocultable sensación de agotamiento: para la mayoría, incluso para varios de los que los formaron, los colectivos, "sólo traen desventajas para la creación individual"12. Aun algunos representantes de Neón, el grupo de mayor notoriedad y convocatoria, reivindicaron "la libertad de hacer la poesía que yo quiero"13. Es decir que a los grupos, más allá de las posibilidades publicitarias y la institucionalización de la camaradería ${ }^{14}$, poco significado se les reconoce $^{15}$. A propósito $-\mathrm{y}$ aunque no es lo determinante, sí tiene un peso

12 Respuesta de Víctor Coral (de Geranio Marginal) para el cuestionario de la revista Imaginario citado en la nota anterior. Añade Coral: "es evidente que la preocupación por la imagen del grupo y el querer siempre dar una impresión de solidez y coherencia, en los posibles planteamientos, mediatizan inevitablemente las opciones individuales que, de hecho, se generan al interior de todo grupo" (p. 6).

13 Ibídem, respuesta de Paolo de Lima, p. 5.

14 Y la posibilidad de generar un espacio, en un medio percibido como cerrado, para la expresión de los jóvenes creadores, como plantean los integrantes de Neón a propósito del surgimiento de su grupo. Véase la entrevista "No somos escépticos ante la vida", mencionada en la nota 8.

15 Mención aparte merecen las palabras de Leo Zelada (seudónimo de Rubén Grajeda, líder de Neón), a propósito de la experiencia de su grupo: “Durante el período 1990-1999, se ha convertido en la agrupación contracultural de los noventa, no sólo en Perú sino a nivel latinoamericano, y que ha pasado a ser de un grupo poético a todo un movimiento cultural y en un fenómeno social, ya que ha movilizado en sus nueve años de existencia a miles de jóvenes en conciertos de música, recitales de poesía, conferencias, etc., en este fenómeno de conjunción de 'postmodernidad y política'”, en Juan Antonio Bazán (comp.). La política ya no es lo que fue. Opina una generación entre dos siglos ("Las "luces" de Neón. De la generación X/Y a la nueva civilización planetaria", sexta parte del artículo "Más allá de la generación X/Y. Nueva cultura política en el siglo XXI"). Lima: Editorial San Marcos, 1999, pp. 143-144. Sería interesante conocer la opinión de sus compañeros de aventura de los años 1990-1993 que, sin duda, marcan una "primera etapa" del grupo, ajena en gran medida a la posterior reaparición liderada casi exclusivamente por Zelada. 
inocultable- también hay que mencionar que al llegar a los noventa, los colectivos de todo cuño se encontraban en retirada o, cuando menos, probaban ya el sabor del desprestigio. Todo esto explica la corta, en algunos casos cortísima, duración de los grupos poéticos surgidos, y da luces para entender que la aparición de Inmanencia, -hecho que de por sí resulta paradójico-, a fines de la década, haya tenido signo opuesto: poética espiritualista y no "urbana", rituales y no actos, y poco afán de convocatoria (aunque sí de notoriedad, como sus pares inversos) permiten su caracterización más como un antigrupo: el reverso de una experiencia agotada.

La cancelación del espíritu gregario va de la mano con la consolidación de otra tendencia: la ausencia de todo sentido parricida ${ }^{16}$. Más allá de las admiraciones o discrepancias, y con buen ojo crítico en algunos casos, los poetas de los noventa, en su mayoría ajenos a la militancia grupal, no han pretendido ser refundadores de ninguna tradición. Lejos de todo adanismo, aceptan su múltiple paternidad, peruana y extranjera. Se han alejado, también, del malditismo que, aunque tuvo una gran presencia en los años 1990 a 1992, ha hecho evidente, en sus últimos estertores, aislados y casi siempre fallidos, el signo de un ya escuchado espíritu adolescente.

Otro rasgo de la poesía de estos años, nítido a poco de iniciada la década, mostró que los jóvenes autores no serían prontamente consagrados: la poca crítica que se ejerce mira por otros lados ${ }^{17}$. El escenario así planteado contribuye al debilitamiento del paradigma del "poeta joven". A lo largo del siglo XX, poetas como Oquendo de Amat, Martín Adán, Westphalen, Eielson, Sologuren, Heraud, Hernández, Cisneros, Lauer y Verástegui o, más recientemente, Chirinos, Mazzotti

16 Ya en 1987, y refiriéndose a la poesía de los ochenta, los autores del prólogo de La última cena señalan: "A partir de entonces [se refieren a los inicios de la década y, específicamente, a la aparición de los primeros libros de Eduardo Chirinos y José Antonio Mazzotti] ser poeta joven ya no significaba necesariamente ser parricida". La última cena. Poesía peruana actual, pp. 11-12.

17 Quizás en el interés de la crítica se puede mencionar las relativas excepciones de Monserrat Álvarez y Xavier Echarri, cuyos Zona dark y Las quebradas experiencias y otros poemas, respectivamente, llamaron favorablemente la atención en los años iniciales de la década. 
y Frisancho, entregaron sus primeros libros alrededor de los 20 años (algunos de ellos apenas con 18), logrando invariablemente el reconocimiento de su "extraordinaria precocidad en el manejo de su propio lenguaje". Es cierto que al lado de ellos están Eguren, Vallejo, Blanca Varela, Delgado, Guevara, Pimentel y otro largo etcétera, que publicaron después de los 25; y que los primeros libros -si bien pueden llamar la atención-, salvo excepciones, nunca son los más apreciados de un poeta. Pero nuestra tradición ha valorado, de manera sobredimensionada muchas veces, la idea de la precocidad poética, lo que, tomando las palabras de Marco Martos, podríamos llamar el "síndrome Rimbaud"18. Los poetas de los noventa, cuya demora en publicar (la mayoría esperó por lo menos llegar al cuarto de siglo) se puede explicar por desconfianza de la suficiencia de su palabra, por cautela o por dificultades materiales para llegar a la edición, han contribuido a recortar el impacto de la imagen del joven poeta ${ }^{19}$. No se trata, por supuesto, de negarle valor a los tempranos logros de algunos poetas, sino de señalar que -es la hipótesis- la consideración de si el poeta tiene veinte, veintiuno o veintisiete años comienza a parecer menos importante: debería quedar claro, en general, que la carrera es mucho más larga de lo que evidencian los primeros libros.

\section{Tres}

Cabe señalar, siguiendo la advertencia de mi introducción, que no considero que los rasgos enunciados sean producto de un conjunto de poetas especialmente dotados para la cancelación de discursos o la consolidación de perspectivas; no se trata, por tanto, de la fundación en los noventa de una nueva tradición. Lo mencionado es resultado, además de la particularidad de las voces en cuestión, del diálogo con

18 Martos hace referencia específicamente a la atención que se presta a un poeta por sus trabajos iniciales. En "Algunos poetas del Perú", texto introductorio de “La generación del 50. Antología poética de la promoción 45/50", en Documentos de Literatura 1. Lima, abril-junio, 1993, p. 12.

19 Aunque alguna crítica ya ha llamado la atención sobre la precocidad inusual de Lizardo Cruzado, José Carlos Yrigoyen o Alberto Valdivia. Véase por ejemplo los comentarios de Ricardo González Vigil a los poetas mencionados en su Poesía peruana. Siglo XX. Tomo II. Lima: Editorial Copé, 1999. 
los procesos sociales del país y el mundo y del desarrollo previo de los procesos literarios en nuestro país: varios rasgos que se observan en los noventa se pueden notar ya, con mayor o menor nitidez, en poetas de las promociones anteriores.

Esto es válido también para lo que sigue: el final, en los noventa, de la hegemonía de la dicción conversacional ${ }^{20}$. "La poesía conversacional ha muerto", declaraba como acta de defunción la poeta y crítica Rocío Silva Santisteban en $1998^{21}$ al iniciar el prólogo del primer libro del novísimo grupo Inmanencia ${ }^{22}$. Aunque algunos meses después -y luego de comentarios-respuesta de otros críticos a propósito de la aparición de libros de jóvenes poetas identificables dentro de la clave coloquial- señaló que no debían tomarse tan en serio las palabras citadas, lo cierto es que la aparición de los libros de Inmanencia ${ }^{23}$ y la frase en cuestión daban cuenta de un hecho central que se sellaba a fines de la década: no la muerte de la poesía conversacional, no su agotamiento como registro válido para la poesía (que lo sigue siendo, incluso entre los jóvenes), sino el cuestionamiento de su posición como centro del canon poético peruano poscincuenta.

Recordemos que la poesía conversacional en la Hispanoamérica de los sesenta (que continúa, como sabemos, las exploraciones que en los años veinte realizó el grupo de poetas -muy interesados en la poesía inglesa y angloamericana- llamado por José Emilio Pacheco

20 Uso "conversacional" en el sentido que la tradición crítica ha dado al término: de modo amplio, la poesía narrativo-coloquial hispanoamericana que se consolida en los sesenta y que recoge las enseñanzas fundamentales de la tradición anglosajona del siglo XX; el "británico modo", como lo llamaron los autores del prólogo de La última cena. Poesía peruana actual.

21 Aunque Rocío Silva Santisteban se refiriere, al parecer, a la línea más "clásica" del conversacionalismo, su afirmación -tomada más globalmente, de modo que involucraría incluso buena parte de su propio trabajo poético-es útil para revisar el tema que planteo.

22 Inmanencia (textos de Enrique Bernales, Christian Zegarra, Florentino Díaz y Carlos Villacorta). Presentación de Rocío Silva Santisteban. Lima: Edición de los autores, 1998.

23 El mencionado y el segundo, Regreso a Ourobórea. Lima: Edición de los autores, 1999 (incluye textos de, además de los citados -salvo Florentino Díaz-, Arturo González). 
"la otra vanguardia" ${ }^{24}$ y la antipoesía de Parra) se caracteriza centralmente, como ha apuntado Antonio Cornejo Polar, por "la ruptura del enclaustramiento del lenguaje intrínsecamente poético", que trae como correlato que

... el sujeto lírico pierde, con este hecho, su identificación social. En otros términos, no puede seguir afirmando su identidad como agente especializado de ciertos códigos de uso restringido, consensualmente adscritos al universo de la alta cultura, y su competencia lingüística, antes diferenciadora y jerarquizante, parece sumergirse en la común aptitud de los hablantes de una lengua determinada ${ }^{25}$.

Recordemos, además, que este "acercamiento a la oralidad, a los rasgos de la coloquialidad del lenguaje", como ha apuntado Rodrigo Quijano, se consolida, también, como un intento de vinculación por parte de la progresista ciudad letrada de los sesenta "con lo real social emergente" 26 . Aunque no se debe dejar de lado la existencia de casos como los de González Prada o César Vallejo, por citar dos ejemplos peruanos, que resultan iniciadores de un camino semejante.

En el Perú, luego de la canonización de lo conversacional con el eje que representan Antonio Cisneros, Rodolfo Hinostroza, Mirko Lauer y Luis Hernández, entre los más importantes, asistimos a su radicalización (y no ruptura, salvo en el discurso metapoético) con el vitalismo del poema integral de Hora Zero en los setenta. En los ochenta, en que el panorama es definitivamente más diversificado, la dicción conversacional siguió siendo hegemónica y constituyendo la "línea maestra" dentro de la joven poesía, tanto en los poetas que

24 Pacheco, José Emilio. “Notas sobre la otra vanguardia”. Revista Iberoamericana 106-107. Pittsburg, enero-junio, 1979, pp. 327-334.

25 Cornejo Polar, Antonio. “La problematización del sujeto en la poesía coloquial", en Mc Duffie, Keith y Rose Minc (eds.). Homenaje a Alfredo A. Roggiano. En este aire de América. Pittsburg: Instituto Internacional de Literatura Iberoamericana, 1980, p. 202.

26 Véase Quijano, Rodrigo. “El poeta como desplazado: palabras, plegarias y precariedad desde los márgenes". Hueso Húmero 35, p. 35. Véanse también los comentarios de Peter Elmore a este artículo en el siguiente número de la misma revista: "El poeta como desplazado: las palabras a la intemperie". Hueso Húmero 36, pp. 147-155. 
optaron por una narratividad "culturalista", como en la irrupción del sujeto poético femenino, o en la línea que apostó por la oralidad fragmentada y caotizante, que podríamos señalar como una exploración en los márgenes últimos del coloquialismo.

Si hablo de hegemonía y no de exclusividad de lo conversacional, es porque hubo, en las décadas que van de los sesenta a los ochenta, poetas (y no pocos) que representan caminos alternativos, pero, ya sea por la falta de maduración de sus poéticas, por su poco afán de ruptura o, principalmente, por las dificultades de la crítica para mirar más allá del canon establecido para la consagración del joven poeta ${ }^{27}$, no fueron lo suficientemente atendidos, o en todo caso, sus propuestas, aunque valoradas, fueron relegadas al casillero - prestigioso, es cierto, pero menor- de lo "insular" ${ }^{28}$. En los noventa se consolida el proceso en marcha (la llamada "dispersión") y la poesía discute la primacía de su línea hegemónica: entre los jóvenes creadores un rasgo que destaca es la pérdida (¿el abandono voluntario ${ }^{29}$ ) del centro estructurador de lo conversacional ("culturalista" o "callejero") y, como consecuencia de esto, el aumento en progresión geométrica de los registros por los que se transita.

Si bien esta consolidación se corona simbólicamente a fines de la década con la aparición de Inmanencia -que proclama el retorno a un

27 Es contra lo que reclama Mario Montalbetti en "La retórica de la 'retórica del 60"”. Hueso Húmero 15-16, octubre-marzo, 1983, pp. 228-229.

28 El artículo “Antes del fin. Un acercamiento a la poesía peruana 1975-1994” de Carlos López Degregori (en Humanitas 31, diciembre 94; pp. 15-51) y el libro Generación poética del 60. Estudio y muestra, preparado por él, junto con Edgar O’Hara (Universidad de Lima, 1998), llaman la atención sobre este crucial hecho.

29 Esto es, por ejemplo, lo que comenta César Ángeles sobre la poesía de los noventa a partir de la lectura de Cansancio, de Paolo de Lima: "Existe un manifiesto repliegue hacia las zonas más íntimas del individuo, que quiere echar lejos toda huella o resonancia del lenguaje referencial. Tendencia al abstracto, otra vez. Cansancio. ¿Cansancio de qué? Quizá de esa preeminencia en nuestra tradición poética, rápidamente reseñada al comienzo de este artículo, correspondiente a la segunda mitad del siglo". Ángeles, César. "Los años noventa y la poesía peruana". Ciberayllu (http://www.andes. missouri.edu/andes/especiales/calnoventa/cal_noventa2.html). 
lenguaje misterioso y hasta sagrado-, desde inicios de los noventa, se puede observar que los jóvenes poetas publican sin mala conciencia textos que parcial o totalmente escapan de la línea central anterior: es el caso de Eroscopio de Luis Fernando Jara en 1990; de mi libro Rincones (Anatomía del tormento) en 1991; De las causas y los principios (venenos/ embelesos) de Grecia Cáceres en 1992; Escritos en odres de Gabriel Prado y Sapiente lengua de Lorenzo Helguero en 1993; Ritual del silencio de Camilo Fernández Cozman en 1995; Beissan o el abismo de Helguero y Con una mano en la garganta de Jara en 1996; Sahari de Bili Sánchez en 1997, por citar algunos títulos.

La presencia de los mencionados en el panorama de la poesía reciente y la variedad de sus registros dan cuenta de que no se trata ya de voces marginales o insulares, sino de propuestas escriturales tan válidas como las ubicadas en el eje antes hegemónico. Es más, la insularidad, a estas alturas, resulta una categoría de poco probable uso. Lo que en años anteriores pudo tomarse como anacronismo y síntoma de evasión, resulta en los noventa fundamental para el proceso poético y su comprensión ${ }^{30}$. Éste tan notorio cambio en la sensibilidad de los poetas y, parcialmente, en nuestra reducida crítica, ha permitido, además -es una hipótesis-, que poetas de la promoción anterior como Juan Carlos de la Fuente (Declaración de ausencia) o Luis Chávez (La caza del colibrí) $)^{31}$ se animen a entregar a las prensas libros que quizás años antes hubieran debido resignarse a la postergación. Ha obligado, también, a repensar los patrones que dirigieron los criterios valorativos hasta 1980, cuando menos.

Lo anterior no debe ser tomado, de ninguna manera, como la propuesta de un movimiento pendular en que se pasa de la narratividad

30 Quizás el caso más característico es el de Sapiente lengua, el primer libro de Lorenzo Helguero, que no sólo desafía la univocidad de la dicción conversacional (que, sin embargo, vive en algunos de los textos con pálpitos de antipoesía), sino que, totalmente a contracorriente, se compone de veinticuatro sonetos que dialogan con Martín Adán, Darío o los clásicos españoles. Si el primer libro de este joven hubiera sido publicado diez años antes, posiblemente habría sido descalificado de inmediato o relegado a la condición de "curiosidad"; en 1993 fue celebrado y, pronto, antologado.

31 Ambos publicados por Asaltoalcielo editores en 1999. 
coloquial a la sacralidad del verbo o a un clasicismo literaturizante. Es cierto que algo de sístole y diástole -o de momentos de aventura y de vuelta al orden, para usar los términos de Guillermo de Torretienen los procesos literarios. Pero estamos aquí, aparentemente, en un momento que puede leerse como de síntesis o, desde otro ángulo, de plena convivencia. De hecho, al lado de los libros mencionados dos párrafos arriba, están también textos (como Zona dark, de Montserrat Álvarez; Las quebradas experiencias y otros poemas, de Xavier Echarri; (Nadie se mueva), de Gastón Agurto; Concierto en el subterráneo, de Alonso Rabí; Pista de baile, de Martín Rodríguez-Gaona, Lima o el largo camino de la desesperación, de Carlos Oliva; El libro de las señales, de José Carlos Yrigoyen; La gruta del cangrejo, de Luis Aguirre; Abajo, sobre el cielo, de Roxana Crisólogo, o Éste es mi cuerpo, de Lizardo Cruzado, por sólo citar algunos), que desarrollan eficazmente algunas de las posibilidades de la amplia gama conversacional. Lo que ocurre es que, en un escenario que podríamos llamar posmoderno ${ }^{32}$, las fuentes francesas y españolas (predominantes en los cincuenta) y las fuentes anglosajonas (esenciales en la dicción narrativa-conversacional 19601980), junto con las clásicas, las orientales, parcialmente las andinas y el siglo XX peruano en pleno conviven sin rivalidades ni acusaciones en la biblioteca de los noventa, al lado, además, de las referencias massmediáticas, el rock, la cultura popular...

Es innegable que este camino de dispersión tiene, como ya quedó señalado, raíces en la poesía peruana de la década anterior y -si hay el ánimo de mirar con más profundidad- quizás antes. La heterogeneidad es ya patente en los ochenta, sin embargo,

... fue vista con desconfianza, desdén y mal disimulado temor: al ser irreductible a las definiciones se le tildó de "retro", de evasiva, de peligrosa y hasta hubo quienes se dedicaron, con morboso deleite,

32 Posmodernidad literaria enmarcada en una posmodernidad social/cultural entendida "no como una nueva episteme que sucede a la modernidad sino como la comprensión de que la modernidad consiste en "múltiples respuestas/propuestas", es decir, que hay múltiples modernidades, múltiples formaciones sociales y culturales que constituyen la modernidad" (Yúdice, George. “¿Puede hablarse de posmodernidad en América Latina? Revista de Crítica Literaria Latinoamericana 29. Primer semestre de 1989, p. 108). 
a evaluarla con los mismos criterios empleados para evaluar a las promociones anteriores ${ }^{33}$.

Este gradual proceso de pérdida del centro (saludable aunque desconcertante para quien se lanza a la creación con pocas seguridades y muchas puertas abiertas, lo que equivale a decir que sin un plano que indique la mejor ruta, pues ésta no existe más, por ahora) exige, entonces, repensar la productividad o la insuficiencia del eje dicotómico conversacional/no conversacional, pues son múltiples los otros componentes que deben ser tomados en cuenta para la ubicación de las poéticas en curso. La poesía de la última hora es, más que las de las promociones anteriores, el campanazo que obliga a dejar de lado las etiquetas o, en todo caso, utilizar muchas más de las acostumbradas. Los esquemas, más que nunca, se enfrentan con sus limitaciones.

Esta exigencia crítica, paradójicamente, coincide con un tiempo en que, aparentemente, menos atención se le brinda a la poesía. Sea porque por fin, con lucidez propia de estos desengañados tiempos, se evidencia que el poeta que, de uno u otro modo forma parte del establishment literario - de sus puertas de ingreso o de sus ventanas marginales-no participa, como tal, del devenir de los procesos sociales (ni de los reivindicativos de los sectores marginados ${ }^{34}$ ni de los más "sofisticados" del mercado ${ }^{35}$ ); sea porque, como señalaba Luis Aguirre, en 1998, "no hay grandes nombres en la década del noventa"36, o sea, nuevamente, por el desconcierto de un panorama complejo y la relativa

33 Chirinos, Eduardo. "Veinte años de poesía peruana". Cuadernos Hispanoamericanos 588, junio 1999, p. 33.

34 En 1983 advertía Óscar Malca, frente a las propuestas de las décadas anteriores: “Me parece ridículo seguir repitiendo que la poesía sirve a la revolución y las masas populares; la poesía no sirve, es una cosa que circula, que se impregna de lo que está en los círculos sociales, las contradicciones políticas, pero no interviene, no tiene ningún papel". (Malca, Montalbetti, Santiváñez y Verástegui. "Sobre la poesía peruana última. Una conversación”. Hueso Húmero 17, abril-junio 1983, p. 34). La opinión, claro, resulta válida en el marco de la literatura "oficial" o "culta". Más allá de estos linderos, donde hay un amplio territorio lamentablemente poco estudiado, otro es el cantar.

35 Espacios en los que la narrativa ha entrado con pie más seguro.

36 La cita completa es: “En resumen, no hay grandes nombres en la década del noventa, pero, eso sí, más de uno que promete. Y si la constancia, el trabajo 
poca bulla de sus protagonistas, los años noventa vieron reducirse los espacios dedicados a la joven poesía en la prensa y las revistas especializadas. Ya en 1993, Carlos Garayar señalaba:

No es que haya dejado de publicarse, sino que, a despecho de la multiplicación de recitales y de la aparición de numerosos "primeros libros", la poesía recibe menos atención que antes. Tal vez sea una apreciación muy subjetiva, pero el interés por los poetas más jóvenes no se parece ni de lejos al que en su momento suscitaron los del 70 y, no digamos ya, los del 60. Lo mismo puede afirmarse de las revistas poéticas, que ahora son mucho más fáciles de editar, pero que carecen del peso y la capacidad de convocatoria que tuvieron en las décadas pasadas ${ }^{37}$.

\section{Cuatro}

De modo tentativo se pueden señalar algunas líneas que los poetas de los noventa recorrieron y, hoy, ya terminada la década, siguen recorriendo. Cabe notar que no se trata de compartimentos estancos ni de escenarios que exigen fidelidad exclusiva, sino de "espacios" por los que se está "de paso", en los que se habita durante algún tiempo o, en algunos casos, en los que un poeta ha fijado su voz, quizá definitivamente.

Son dos las variables en conjunción las que sostienen la organización de estos "espacios": la configuración del sujeto poético y la construcción del lenguaje. Con relación a la pertinencia de lo primero vale la pena recordar que "es a través del discurso que el sujeto construye el mundo y se construye a sí mismo" ${ }^{\prime 38}$, y que

poético individual y las musas ayudan, tendremos algún poeta de verdadera importancia". Fascículo "Echarri: Quebradas experiencias", sobre los años noventa, de la colección Literatura peruana, del diario Expreso, p. 300.

37 Garayar, Carlos. "Invierno lírico" (Nota que acompaña la selección "Gente trabajando. Breve y provisional antología de los nuevos poetas peruanos", preparada por el propio Garayar). Suplemento Artes y Letras de El Mundo, 18-19 de marzo de 1995, pp. 4-5D.

38 Scarano, Laura. "Hacia una teoría del sujeto en la poesía española". Introducción del libro colectivo La voz diseminada. Hacia una teoría del sujeto en la poesía española. Buenos Aires: Editorial Biblos y Universidad Nacional de Mar del Plata, 1994, p. 13. 
... el sujeto es una función y precisamente por ello en él se inscribe la huella de una práctica social. [...] Por eso, hablar de la función impersonal inherente a la escritura como práctica significante no es lo mismo que hacerlo de un supuesto e hipotético sujeto impersonal inexistente, como productor de esa escritura [...] y entenderlo como ajeno a cualquier sobredeterminación ${ }^{39}$.

Sobre lo segundo, cualquier justificación de su importancia para el diseño de líneas poéticas resultaría redundante.

Una revisión atenta de las posibilidades por las que los jóvenes han transitado, da muestra de la permanente dialéctica continuidad-ruptura que suponen los procesos poéticos. De hecho, como se podrá observar, varios de estos "espacios" han establecido claros puentes de continuidad con lo hecho por las promociones anteriores; otros, sin embargo, suponen caminos en cierta medida inéditos. Algunas de las líneas que se mencionarán a continuación están más vinculadas entre sí que otras; esto, que posibilitaría que además de ellas pudiéramos hablar de ejes o polos en los que confluyen varios "espacios", nos llevaría de regreso, sin embargo, a un grueso esquema bipolar conversacional/no conversacional (u otro alternativo) que -es la propuesta- no llegaría a reflejar de modo cabal no sólo lo ocurrido en estos últimos años.

Es fundamental que la crítica no se deje ganar por los afanes de simplificación, máxime cuando se trata de un panorama aún muy poco explorado. Por ello, y puesto que toda propuesta de un esquema de comprensión supone eso: una esquematización, es decir una simplificación de la realidad, hay que anotar que no será extraño que encontremos a un mismo poeta en más de una línea. También hay que decir que postular estos "espacios", como haré a continuación, no implica una pretensión homogeneizadora: los poetas reunidos en uno no son -no tienen por qué serlo- iguales entre sí; sin embargo presentan rasgos en su poesía que los acerca, permitiendo así establecer un mapa que refleje, al menos aproximadamente, qué está pasando con las propuestas de escritura de los poetas de los noventa.

39 Jenaro Talens en "Práctica artística y producción significante", citado por Scarano; op. cit., pp. 14-15. 
Es innecesario advertir que ningún esfuerzo organizador puede suplantar la aproximación directa a los textos. Tampoco, lo sabemos, un esquema de conjunto reemplaza la revisión detallada de la obra de cada poeta. Tareas que quedan anotadas para revisiones más exhaustivas y para el deleite del lector.

a) Un primer "espacio" corresponde a la revitalización-de acuerdo con modalidades distintas que coinciden, sin embargo, en la irreverencia, en el uso de un lenguaje directo y la recusación de los tópicos y formas del "buen decir" poético- de la tradición del poeta maldito.

El malditismo urbano "noventero", que como quedó señalado tuvo su apogeo en los inicios de la década, continuó en buena medida el eje Hora Zero-Kloaka y estuvo en diálogo con la "movida subte" rockera que, coincidentemente, tuvo también en esos años su último gran momento. Quizá una de las más cabales muestras de este espacio es Lima o el largo camino de la desesperación (1995), libro póstumo del tempranamente fallecido Carlos Oliva ${ }^{40}$. En él, el poeta, personaje de los poemas, se autoidentifica como vidente: es el profeta del apocalipsis citadino, el elegido para dar el testimonio de la destrucción de la cual él es voluntariamente parte, y que nutre su poesía. El compromiso con la poesía -expresada en una exaltada voz, irreverente y coloquial- lo obliga a sumergirse vitalmente en el "largo camino de la desesperación". De ahí que sus textos -que evidencian un manejo cabal de retórica y un discurso nada novedoso por cierto (nutrido de los poetas malditos franceses, la vanguardia, Ginsberg y los beatniks, Hora Zero y Kloaka, el rock subterráneo)- tengan la fuerza de la honestidad. A diferencia de Oliva, varios otros poetas (quizá el conjunto más amplio en los noventa), hicieron del malditismo urbano, una retórica con excesivo sabor a impostura. La representación de la ciudad, en estos textos, más le debe a un modelo ya prefigurado y repetido que un real esfuerzo creativo ${ }^{41}$.

40 Carlos Oliva (1960-1994), por edad, podría pensarse más cercano a los poetas de los ochenta; sin embargo, su actividad literaria comenzó a ser pública recién en la década de los noventa y vinculado con los jóvenes poetas de ese entonces, como queda claro en su participación como fundador del grupo Neón.

41 A pesar de no ser el suyo un texto plenamente urbano, un caso que merece comentarse es el del "fundador y líder", según su autopresentación, de Neón: 
En el mismo "espacio", aunque con una modulación distinta, se puede ubicar Zona dark (1991), de Montserrat Álvarez. Con justa razón su propuesta concitó gran interés ${ }^{42}$, pues se trata de un libro sólido y muy versátil tanto en el manejo del lenguaje, como en la construcción de sujetos poéticos y en el uso de fuentes poéticas y filosóficas. No se trata de un malditismo meramente urbano, pues a lo largo de las quince secciones del libro se construyen varios escenarios, en los que si bien lo urbano es fundamental, no es, de ningún modo, único. La sensación de caos y clima apocalíptico, además, no están necesariamente unidos a una escenografía callejera del deterioro, sino a personajes que ponen en escena una dinámica de relaciones en la que se evidencia el eje fundamental del libro, éste sí de raigambre maldita: la mediocridad burguesa es puesta bajo el severo ojo (de diversos modos y a través de hablantes y personajes diferentes) del autor implícito ${ }^{43}$ del libro, cuya posibilidad de juicio, y por ende su posición superior, están basadas en el conocimiento de la "verdad"; es decir, en la lucidez que le permite descubrir la miseria humana realmente existente bajo la apariencia de normalidad. Otros rasgos que nos permiten ubicar este libro dentro de la corriente de revitalización del malditismo son, además de las notorias marcas

el poeta Leo Zelada. Su libro, Delirium tremens, lo propone, a través de diversos materiales paratextuales, como el "último de los poetas malditos". Su malditismo, sin embargo, se sostiene en un texto superficialmente transcultural y posmoderno, consecuencia de adquirir, impostadamente, vestiduras de maldito. En una línea semejante a la de Oliva, también destacan sobre el resto los trabajos de Rodolfo Ybarra, sobre todo en su Sinfonía del kaos, y de Julio Durán.

42 Y hasta ahora se le puede seguir reconociendo como uno de los libros más importantes entre los poetas de los noventa, aunque el tiempo haya hecho su trabajo de desgaste sobre algunos cuantos poemas, que parecen ser, sobre todo, el resultado de un formulismo inteligente.

43 Utilizo la propuesta que, para la narrativa, recoge Mieke Bal: “El término lo introdujo Booth (1961) para comentar y analizar los conceptos ideológicos y morales de un texto narrativo sin precisar de una referencia directa a un autor biográfico. En el uso que hace Booth del término, éste denota la totalidad de los significados que cabe inferir de un texto, y no la fuente de dicho significado. Sólo tras interpretar el texto sobre la base de una descripción textual, se podrá inferir y comentar al autor implícito. Además, la noción de autor implícito no se limita, en este sentido, a los textos narrativos, sino que es aplicable a cualquier texto". Bal, Mieke. Teoría de la narrativa (Una introducción a la narratología). Madrid: Editorial Cátedra, 1995, p. 125. 
paratextuales ${ }^{44}$, la deseada autoexclusión del autor implícito (definido por la superioridad mencionada y el consecuente desprecio a/de los otros, los tranquilamente instalados en el seno de la sociedad), el nihilismo, el repudio por toda forma de colectivización, la actitud contracultural y el demonismo (la devoción al dios del mal). También el lenguaje, irónico, directo y agresivo, que incorpora sin tropiezos rasgos de la oralidad de la jerga citadina que alimenta una voluntad antilírica y urbana o se desenvuelve en un registro que homenajea la dicción de las Flores del mal ${ }^{45}$.

A Lizardo Cruzado, que representa una tercera modalidad dentro del malditismo de los noventa, se le puede ubicar en esta línea sobre todo si se atiende al conjunto (incluidos carátula, prólogo y autopresentación en la contratapa) del excesivo libro que es Éste es mi cuerpo (1996). La imagen de enfant terrible posmoderno brota de sus páginas a través del tratamiento irreverente y desfachatadamente irónico, con que busca desmitificar una serie de convenciones y creencias, ligadas sobre todo al ámbito de la intimidad y al entorno inmediato del individuo clasemediero. El adolescente que habla en los poemas -construyendo, de paso, una imagen con frecuencia autodenigratoria de sí mismo- utiliza, como es esperable, un lenguaje directo, claramente antipoético, cargado de un evidente ludismo de cuño vanguardista, que privilegia constantemente las referencias a lo escatológico y lo sexual en su ánimo de irritar a los lectores. Sin embargo, si tomáramos aisladamente los mejores poemas -los que quedarán con todo derecho en una antología de la poesía peruana reciente, gracias al privilegiado manejo de recursos y emociones con que cuenta el poeta- es probable que la imagen de maldito -no así la ácida ironía y el desenfado que son algunos de sus puntos a favor-se diluyera, y apareciera en su lugar otra, más honesta y más interesante.

44 Como el título -que alude a la oscuridad y al discurso de los rockeros subterráneos-, la sombría foto de la autora y el texto de autopresentación de la contracarátula: "En el año de 1991, fecha de tantas muertes y nacimientos, yo, la bien o mal llamada Montserrat, por todos conocida y deplorada, decidí escribir, para las humanidades venideras, unas líneas que no significasen nada en absoluto".

45 En los alejandrinos rimados y organizados en cuartetos de la sección que da nombre al libro: "Zona dark". 
b) Cerca del espacio anterior, pero evitando las posturas malditas que lo caracterizan, éste también tuvo su auge en los años iniciales de la década, aunque sus logros más notorios se hayan dado al final de ésta o incluso después. Se trata de una línea que busca la representación del espacio suburbano y popular, a través de la configuración de un sujeto que se propone como testigo o protagonista. Lima pobre, por lo general, con sus personajes desgarrados, sus voces fragmentadas, sus carencias materiales y afectivas; con sus arenales, sus burdeles, sus microbuses; con su rock, su chicha y los resabios cantineros de música criolla; Lima pluricultural, híbrida; humana y miserable...

Definitivamente los referentes más inmediatos de esta línea, una de cuyas más interesantes muestras es Abajo, sobre el cielo (1999) de Roxana Crisólogo, ex integrante de Noble Katerba, son Hora Zero, Kloaka y, más cercanamente, Rodrigo Quijano. La representación poética de esta Lima popular e informal estuvo marcada, a inicios de la década ${ }^{46}$, por la reiteración de imágenes, personajes y lenguajes que ofrecían un limitado reciclaje de los referentes mencionados. El libro de Crisólogo -educada, sin duda, entre esos jóvenes en cuyas voces ese discurso poético lucía ya cansado e improductivo-, se distingue, sin embargo, por evitar la retórica fácil de esos años. Abajo, sobre el cielo articula, desde sus poemas -que, como retazos recorren estancias, héroes anónimos y personajes conocidos- la intensa imagen de una urbe caótica, quebrada, dolorosa; pero viva y múltiple, y utiliza para ello un tono altamente lírico (quizás, lo que a sus contemporáneos les hacía falta para combatir el inmediatismo y la repetición), incrustado en el meollo de las sucias y solitarias calles citadinas ${ }^{47}$. En su segundo libro, Animal del camino (2001), Crisólogo ensaya una propuesta más ambiciosa: la representación no sólo ya de Lima, sino también de la contracara de las ciudades europeas del cambio de milenio. Así,

46 Sobre todo en revistas o recitales.

47 Cercana a la del primer libro de Crisólogo, es la propuesta de Una vela en el desierto (2000) de Carolina Fernández, que, aunque con menores logros como conjunto, añade el interés por la introspección del yo (múltiple) y las indagaciones en los recovecos del amor y el deseo. En el plano del lenguaje, también directo, coloquial y fragmentado, se suma el uso de recursos (visuales, sonoros, gramaticales) que remiten a las exploraciones vanguardistas. 
aparecen gitanos, negros, rusos, inmigrantes, subempleados, etc., que se hermanan, en el libro, a los habitantes de la Lima suburbana. La propuesta, sin embargo, excede los resultados reales y la voz cae en varios momentos en un descriptivismo que no levanta suficiente vuelo.

En una propuesta cercana, Miguel Ildefonso -quien en la primera sección de su libro Vestigios (1999) construía sus sujetos como testigos de una Lima nocturna y marginal, con un hábil manejo de la tradición, pero todavía con muchas deudas con una retórica que evidenciaba su desgaste- entrega, en la primera sección de su nuevo Canciones de un bar en la frontera (2001), "Cuaderno del desierto de El Paso", un extraordinario retablo que da muestras de una madurez dentro de esta perspectiva: se trata de un conjunto que, combinando una intensa lírica, elementos narrativos, estructuras dramáticas, fragmentarismo, hibridismo lingüístico, va construyendo una imagen del mundo de la frontera del desierto tejano (donde vive desde hace algún tiempo). Un fragmento de "Épica de las tribus", el que sea quizá el mejor poema de la sección, permite dar más luces sobre lo que señalo:

el desierto era el insomnio de las tribus-era pues el sol atrapado en esa malla

eléctrica era el coyote que se tiró del puente-no me dejes ahogar en el río gritaba

no pues no seas gacho reía antes de ser-comido por las turbias aguas del Grande

porque el desierto es maldito-y no te juntes

llévate agua y júrate que lo cruzarás-y esta noche estarás a mi diestra por dios las tribus creían en la bondad-del desierto de Guadalupe mijo -decía- esta vela te llevará-y te limpiará no te pierdas ahora los países abajo hacían fila para cruzar-dejando casa dejando lenguas leguas atrás

\section{se bautizaban en el río}

y pocos vivían para contarlo luego-luego no importa que se le olvide mira este desierto -te digo- antes de quererlo escúpelo 
para que así veas que ni así te responde-él compró una falsa identificación

pero sólo alcanzó a cruzar un falso río-cayó en una boca grande definitivamente la boca del Ogro-desiertos de amor todos iguales desiertos de Nueva York de Lorca-Oh pirámides sin misterio entonces el desierto era chicano-el desierto era un melodrama

\section{que las tribus veían por televisión}

dime si el desierto abarcará nuestro silencio decidme, Dante, ¿por qué me haces esto?

_ ella recapitulaba mientras él nacía de entre las aguas de sus ojos desde antes de llegar al desierto desde antes de cruzar los puentes para pisar la Vita Nuova romper las páginas en que Beatrice moría en que Florencia no florecía antes de amar ya te amaba _ decía el vaquero a la muchacha que a la mala había subido su alma

adonde mires Dante verás el desierto pero no te sientas mal que el desierto te dará de mí nuestro lenguaje todo desierto, recuerda, es un lenguaje entre dos cuerpos desnudos todo desierto así no es soledad jamás jamás entonces me olvides porque adonde mires estará el desierto

(ellos hablan mientras afuera llueve mientras afuera se incendian las tribus mas el desierto es una exacta dimensión en una frontera mojada) -yo era un eco que naufragó en tu cuerpo los vestigios de mi biografía se remontan a Apolo: Mi corazón es ilegal Mi alma es mojado Mi tristeza no tiene Visa 
antes de la mitad del camino // de mis sueños

me desterré // 500 años adelante \& ella cruzó

el Arno Grande // ella encima del desierto de mi alma

la Madre Patria // la lengua en Rojo

-no me mires así chiquillo que me da vergüenza (decía)

entonces escucha (respondió):

la noche es clarísima

en cada punto de tu cuerpo se descifra el universo

el desierto no miente

es duro atravesarlo pero no te miente

c) Los poetas de los noventa exploraron algunas dimensiones del coloquialismo y el discurso de la cotidianidad que, quizás, encuentran sus antecedentes en algunos textos (los menos celebrados) de Manuel Morales y del emblemático y siempre múltiple Luis Hernández. Lo coloquial, además de la exención de ornamentos reconocidamente "literarios" (léase "lengua poética"), no se asocia a un proyecto de representación de los sectores subalternos de la sociedad (claro en el "espacio" anterior), sino que apela a una comunicación aparentemente directa de experiencias cotidianas por parte de sujetos claramente identificables con la clase media. Alguien podría acusar a este "espacio" de autobiográfico y simplista; pero es claro que en sus más interesantes representantes lo que hay es un proyecto literario (y por ello una retórica, en el mejor sentido de la palabra), no la transcripción directa de vivencias y emociones de los autores. No se piense, entonces, que se trata de una poesía ligera o light. El adelgazamiento del mundo que existe en los textos responde sin duda a otros objetivos.

Libros como el segundo de Victoria Guerrero, Cisnes estrangulados (1996), -que construye (con buena mano para la síntesis) el espacio de una voz adolescente enfrentada al drama de crecer $^{48}$-, o Cansancio (1995) de Paolo de Lima -que combinando lirismo y medida norma juvenil, propone una visión melancólica e intimista del entorno: la ciudad vista desde la ventana del cuarto, la mujer, la poesía-, son

48 Que, a su vez, es un refugio con el cual la autora busca alejarse del seguro conversacionalismo de su primer y bien comentado libro, De este reino (1993). 
muestras de una poesía que opta -a través de un coloquialismo no excesivo- por la intimidad y el espacio inmediato como refugio frente al mundo de afuera, amenazante y al acecho (explícitamente en Cansancio) ${ }^{49}$. También Entre la panza y el corazón (1999) de Martín Sánchez Ríos, ofrece un mundo construido desde la mirada a lo inmediato (la mujer, los amigos, el perro), pero que se proyecta más allá (el barrio, la ciudad). A diferencia de los anteriores, aquí la norma lingüística es decididamente desenfadada, irreverente, antipoética; pero como ellos, la aparente trivialidad encierra su lado más interesante: el desconcierto, el miedo, la soledad; signos nada inocentes de la juventud desconcertada de fin de siglo.

En una dirección semejante, pero con una contundencia que lo convierte quizá en el mejor representante de esta corriente, Martín Rodríguez-Gaona ofreció Pista de baile (1997) luego de una primera concreción de su búsqueda en Efectos personales (1993). La opción de Rodríguez-Gaona no es un coloquialismo mesurado ni un desenfado callejero; él desarrolla una propuesta que puede llamarse hipercoloquial: la ilusión de la oralidad llevada a sus extremos: bullente, desatada, fragmentada (reforzada por el manejo constante de la segunda persona), aunque matizada por momentos de lirismo o frases cuya contundencia evidencia lo coherente de la propuesta. Ajustada a una poética de lo cotidiano (de lo ultracotidiano), la voz de Rodríguez-Gaona inauguró un espacio propio, quizá la más interesante renovación de la dicción conversacional en los noventa. El libro es un retablo hecho de imágenes de ceremoniales y ritos de la posmodernidad provinciana de nuestra capital en el que se va develando -con una mirada implacablemente lúcida y áspera- la triste rutina de sudorosos y excitados danzantes barranquinos o, en suma, de desesperados seres que quieren asir la engañosa sensación de seguir vivos a como dé lugar en un mundo como éste, que incluye al propio Yo de los poemas, partícipe del vertiginoso letargo:

4921 pepas de amor y una canción desentonada (1992) de Verónica Álvarez, Chico de mi barrio (1998) de Doris Bayly o El perfume del camaleón (1997) y Cajón desastre (primera prueba) (2000) de Fernando Olea se pueden añadir a la lista, aunque sin un matiz marcado de refugio frente a lo exterior. 
¿Cuántas instituciones lanzan a sus críos

a la programática diversión de un fin de semana?

"Un viejo sifilítico con súbitos ímpetus lésbicos"

No lo sé, Papito, cuenta todos esos autos

y los colectivos,

tendrás un motivo para no ir a casa.

Antes debes resolver una imagen, aquella mujer que aparenta ser Alice Liddell y conversa amigablemente con desconocidos, recostándose allí, junto a la fuente.

Pero si tú nunca has captado nada, en este barrio corren muchas aguas y eso no asegura un flujo perenne. Puedes pasear, emborracharte y vomitar mas a $9,000 \mathrm{Km}$

tu abuelo morirá sin haber visto el rostro con el que despertarás mañana.

Eso y no otra cosa

es lo que las Dalinas llaman "LA ALEGRÍA DE VIVIR" . Los olvidos nunca son gratuitos. En este mismo parque unos cuantos ancianos te hacen recordar las monedas que te sobran

para ser feliz.

Y todo simplemente por cuidarte el carro-

"Ya, no grites que nos lleva el Serenazgo".

Lo único que queda ahora

es perseguir la emoción

y dibujar

luces, sonidos y olores

que hagan creer que esta noche

valdrá la pena. 
Se puede ir a Quilca, el trago es

más barato

y te ahorrarías un pasaje (¡Qué pena!)

Porque Barranco tiene su encanto:

Podrías levantarte a una ruca

y arrinconarla detrás de los jardines,

pegarle, penetrarla, eyacular

deliberadamente dentro

para ser por una sola vez

inmortal ${ }^{50}$.

Frente a la soledad, el vacío y la velocidad de las multitudes, está la contraparte: el espacio de la casa y el amor, duradero y de baja intensidad, pero que acaso puede ser sostén de la existencia. En el centro, entre el furor y lo apacible, sin embargo, se juegan las decisiones, que cada uno debe tomar, como plantea "La eternidad está enamorada de los frutos del tiempo", poema que rompe con el tono del libro, proponiendo un ritmo letánico memorable.

También La gruta del cangrejo (1999) de Luis Aguirre se puede inscribir en esta línea. En este libro, a través de un lenguaje coloquial que no rehúye de metáforas ni símbolos (pero sin alarde ornamental), el hablante poético rememora espacios cotidianos (la casa familiar, sobre todo) para plantear oblicuamente una serie de preguntas sin respuestas suficientes: una poesía reflexiva (sin pretensiones filosóficas, pero con sabiduría humana) desde los datos del diario vivir. Es en la segunda parte ("Cangrejo en el hoyo celeste"), en que una muerte accidental aparece también como dato cotidiano, que La gruta del cangrejo alcanza su mayor vuelo.

50 Fragmento del poema "Nada es nada en un lugar en el que está a punto de suceder todo". 
Así como sucedió con el malditismo urbano, cuya cáscara retórica fue profusamente imitada por jóvenes poetas, también en esta línea se observa la tentación del facilismo, que lleva a la ilusión de hacer poesía con sólo consignar las experiencias propias en una lengua lo más sencilla posible. Lamentablemente esta posibilidad ha sido estimulada por propuestas ${ }^{51}$, en su origen interesantes; pero que no han planteado con claridad que la poesía demanda no sólo talento o sensibilidad, sino también (y quizás en mayor medida) trabajo. Plantear una comunicación plena con un público lector que se desea creciente no debe llevar a descuidar el oficio y el aprendizaje del poeta, indispensables para que la comunicación soñada no descienda al nivel promedio de los productos massmediáticos.

d) Definir la veta culturalista no es novedoso, pues en los noventa ésta asume las herencias de las promociones anteriores: lenguaje conversacional; explícitas referencias a fuentes librescas, musicales, sagradas o cinéfilas, planteadas como homenajes o parodias; configuración de una poética de las máscaras; reciclaje de mitos y tópicos literarios, armonía sonora; gusto por lo lúdico y lo moderadamente irónico y cuidado formal son algunas de sus coordenadas. Los referentes centrales en la tradición peruana están dados fundamentalmente por los poetas del eje sesenta-ochenta (saltando el horazerismo setentista), aunque no se omiten las aprovechadas lecturas de otras voces (y un amplio espectro entre los poetas extranjeros). No se debe caer en el error -a partir de la descripción hecha- de pensar que se trata de una línea en la que lo fundamental es el correcto manejo de una retórica canonizada de modo que, al usarla, el poeta asegura su prestigio. Es cierto que se trata de una buena escuela para el manejo del verso, el diseño de la música y el control de la emoción en los poemas; pero es mucho más que eso y son varios los libros que, en la década, presentan poemas memorables y voces personales. Citemos, por ejemplo, los dos primeros libros de Alonso Rabí, Concierto en el subterráneo (1992) y Quieto vaho sobre el espejo (1994), los conjuntos de Las quebradas experiencias y otros poemas (1993) de Xavier Echarri, previos a la parte que le da el nombre al libro, buena parte de Callado cielo (1994) de Julio del Valle; además de De este reino (1993) de Victoria

51 Como las de Eduardo Rada y sus proyectos de "Poesía masiva". 
Guerrero, Intolerancia (1995) de Eduardo González Cueva y el primer libro de José Carlos Yrigoyen, El libro de las moscas (1997).

Sin embargo, es por lo menos interesante reconocer que varios de los poetas que han inscrito sus libros iniciales en esta línea, en entregas posteriores no han permanecido en el centro de la dicción conversacional, sino que han modulado su voz en diversas direcciones, que permiten hablar de una revitalización de esta línea o de su proyección hacia otras. Así, Alonso Rabí entregó En un purísimo ramaje de vacíos (2000), en el que gana terreno el acento lírico que se observaba en la sección final de Quieto vaho sobre el espejo, sin que ello signifique el abandono de la lectura aprovechada de la tradición, en este caso la del amor, que se remonta hasta la tradición medieval del dolce stil nuovo. En sus páginas, además, en las que se extrema la concisión y la presencia del silencio, la perfección formal no está reñida en absoluto con la capacidad de conmover de sus versos.

Xavier Echarri, por su parte, en el conjunto "Las quebradas experiencias" abandona la seguridad de su palabra canónica (sobre todo la de "La hermandad del alacrán") y se sumerge en el discurso fragmentado y caótico (el quiebre de la confianza en el Yo), de subversión erótica (el amor en un mundo al revés) y lingüística (diversas voces en diálogos entrecortados de múltiples registros), que logra -con sus resultados extrañamente innovadores en el panorama de esta década- dialogar con estos tiempos, tan fragmentados y polimorfos como sus poemas:

La distancia estética no busca sino abolir toda distancia, el nuevo sueño que parte de estos labios y los parte.

Nace de ti y se expande, ondas de sangre,

pero marea plateada, o sal, gimiente.

La poesía cae como un ancla flotante, la piedra del molino rodando toca los cuatro puntos cardinales:

por ella bogas, lastre de diez galeotes, y uno de ellos se pierde en la pared del llanto.

“Hicimos la vivisección, pero no había nada, palabra, salvo tal vez un pataleo, un escozor repentino, pero más hondo".

Canta el deseo temblando en las barbas del gallo, ríen los monos descolgados del techo, los frutales 
del camión se derraman, y provocan una colisión colectiva, un choque múltiple.

“Entonces cuando sacudí el árbol llovieron los mangos

y uno casi me mata sobre el pasto".

Cuarto creciente hacia todos los flancos. Todo es piel: quiero

la negación de la piel, que también es piel, como la ropa.

Son voces, voces, veces de rayar con zigzags un corazón callado.

Verás angelicales demonios royendo su médula, impregnando silencio en tu silencio.

Verás un torreón desbaratado de cabellos, y no sabrás que no saber es humano.

"Admitido, extranjera, dices bien, pero siendo así ¿qué utilidad tiene el amor para los hombres?"

No sucede, pero es sucedido, (no ocurre, pero es transfigurado).

El predicador ha olvidado el rosario en el colchón del monaguillo.

La catedral está rota y se mantiene en pie.

El altar está hendido, los oficiantes sudan, se contorsionan, la tormenta de fuego que no cesa, y gira y gira sin jamás detenerse,

y los cuerpos desnudos chocan, gimen, vociferan, se atenazan con uñas y dientes hasta que nueva furia en el viento los parta,

y allí al recordar sollozan, y después sollozan sin recordar la causa.

Alguien ha envejecido de pronto de lado.

Alguien sabe que vivir es mejor que un dolor que ya no se soporta.

Pero el otro se ríe, y hace muecas: eh mono, dime

un mamey resbalando por un lomo celeste, ¿qué es?, ¿es

posible tus dientes en su carne aromosa, o tu lengua sorbiendo sus lágrimas de aceite?

Todas las pieles

suaves bajo mis dedos-árboles.

¿Y el chibolo? ¿dónde anda el chibolo? 
-Anda perdido en los desagües (a la caza de bobos) ${ }^{52}$.

También Yrigoyen emprende una búsqueda más ambiciosa -que ya se podía prefigurar en los poemas menos clásicamente conversacionales de El libro de las moscas. En El libro de las señales (1999) -un solo y extenso poema dividido en ocho partes- asistimos a un complejo recorrido (que sitúa muchos de sus hitos en una supuesta Europa Oriental de posguerra) que -a través de temas (el poder, la autoridad paterna, la homosexualidad y la libertad del amor, el racismo) y símbolos- engarza sentimiento lírico con continuidad narrativa, alcanzando como resultado un texto de profunda intensidad que no esconde su voluntad interpelativa:

No soy de los que buscan temas

complicados o difíciles

más bien les temo

y me emboscan en el lugar menos

pensado, hace un tiempo

bajaba un camino de noche junto a una chica hebrea

estaba perdida, era medio sorda

yo era corresponsal de guerra

íbamos los dos hacia un pueblo

medio polaco medio ruso

yo buscaba reposo, ella se dirigía

a su casa

son épocas sombrías, dijo la chica

Orestes estaba perdido en el desierto

negociando la paz con los lagartos y las ratas

las nubes nos niegan su perfil

y crecen los cardos sobre el sueño

de los obispos

pensé ¿es acaso papel de las nubes

o de los cardos

52 Fragmento del poema "Historia de un amor al revés (voltéate, por favor, dame la espalda)". 
decidir la caída

de un estado corrupto?

no es tampoco, en todo caso

papel de los hebreos

que tanto temen a nuestra buena policía

y tienen tan mala literatura

cuando llegamos al pueblo

vi entre las torres y las alambradas

una columna de humo que subía

desde el medio de una feria

la chica se despidió

y antes de entrar a su casa me dijo

ahora la Historia vaga por la tierra

con la boca llena de carne

No soy de los que buscan temas

complicados o difíciles

el tiempo que utilizo para pensar

lo desperdicio

buscando chicos en los urinarios

y en las plazas

concertando citas con ellos

en los jardines

y en las discotecas

sin embargo hay ocasiones

en las que me detengo a reflexionar un poco

la guerra había terminado

yo era corresponsal, mi trabajo

intuir si la ligereza

era la que había marcado con lápiz rojo

las puertas de las casas de los

$$
\text { muertos }^{53} \text {. }
$$

53 Fragmento de la parte 4 de El libro de las señales. 
Otros poetas han dado sus primeros libros en el marco de una poética conversacional ya replanteada. Así, Diego Otero, en su Cinema Fulgor (1998), combina el dialogismo y el cuidado formal con el vuelo de una ensoñación sobresaltada, construyendo una ciudad de la magia y la memoria, y en ello mismo, del desgarro y del dolor. Víctor Coral, por su parte, en Luz de limbo (2001), une algunos de los rasgos más frecuentes de lo conversacional (narratividad, homenajes, norma coloquial, etc.) con un alto lirismo, reforzado por la construcción de su hablante bajo la figura del poeta, lo que permite que cada poema sea, a la vez, una sutil reflexión sobre la poesía. También Fernando Velásquez en su inteligente y lúdico Pequeñas alegrías gramaticales (1997) y Humberto Polar, en los distintos conjuntos de su lamentablemente poco atendido Poesía 1982-1995 (1998), ensayan posibilidades diversas, varias de ellas en los márgenes del amplio espectro conversacional.

e) Entre la dicción coloquialista engarzada a lo cotidiano y la culturalista, se sitúan las coordenadas centrales de esta otra línea, cuyos acentos propios, sin embargo, justifican su diferencia: en ella se construye un sujeto autobiográfico que tiene encargada la tarea de recuperar la memoria familiar. Decir sujeto autobiográfico no implica proponer una traslación automática del autor del libro al centro del poema; el hablante, aunque en algunos casos coincida con el nombre del autor o se identifique con su historia (que es de hecho parte de su basamento), es un personaje construido, mediación literaria y posee un estatuto distinto al de los seres reales ${ }^{54}$. El lenguaje de fácil acceso y fuerte narratividad, reconstruye -desde una sensibilidad que incluye la nostalgia, pero que ha sabido sortear cualquier riesgo de descalabro sentimental-, en términos generales, un espacio familiar (limeño o provinciano) que se plantea como columna vertebral para el proceso de aprendizaje de la vida del hablante poético.

54 Señala Laura Scarano que esta "inmersión del autor en el discurso por un lado le otorga un estatuto ficticio convirtiéndolo en función textual y por el otro apela a una convención de lectura no ficcional que atribuye veracidad a los enunciados del hablante (discurso autobiográfico). El lector opera otorgando credibilidad a dichos enunciados, aunque sigue consciente de funcionar dentro de la convención de ficcionalidad que rige los textos literarios; sabe que está frente a un poema (no a un acto de habla del autor real)". En "Hacia una teoría del sujeto en la poesía española”. Op. cit., p. 20. 
Casa de familia (1995) de Selenco Vega es uno de los libros de mayor interés que se inscriben en esta línea. En su libro, colocados como en un panteón familiar, van apareciendo madre, padre, abuelos, tíos, en diversas escenas que corresponden a los recuerdos de la infancia ancashina del sujeto poético o a las narraciones oídas de sus mayores; en uno u otro caso, la voz, ahora adulta, conversa con los personajes que su memoria reconstruye y permite el ingreso de una dimensión mítica ${ }^{55}$; se contribuye, así, a la complejidad del libro, pues los varios niveles narrativos suponen, al mismo tiempo, configuraciones culturales en diálogo. La dicción, narrativa como se señaló, recoge, sobre todo, la herencia de la tradición coloquial (en el Perú son Cisneros y Watanabe sus fuentes más cercanas), pero no omite cierto tono oralizante, probablemente bebido en la propia infancia del autor, que opta, sin embargo, por no incorporar una norma diferenciada en el juego de voces que se escenifica.

Cerca de Casa de familia en cuanto a la recuperación de la memoria familiar provinciana, se encuentra el Libro de Daniel (1995) de Javier Gálvez, aunque su tono es menos coloquial y narrativo (se aproxima, por esto, en alguna medida, a la ritualización del espacio poético que caracteriza una línea posterior) y bebe directamente, además, de fuentes más universales, como la griega o Saint-John Perse; o de Eielson o el primer Hinostroza, entre los peruanos. El personaje poético -situado en la infancia- de mano de sus abuelos podrá descubrir -a partir de la recuperación de la memoria familiar- los significados del ser y del existir y el sentido del mundo que contempla: para ello, sus abuelos, de tierna estatura mítica, lo enfrentarán a esa especie de rito de pasaje que es la segunda parte, "Imágenes para fijar la mar".

Gastón Agurto construye un universo cercano en (Nadie se mueva) (1999), pero ubicado fundamentalmente en la ciudad de Lima. No es por ello un libro urbano; sigue siendo, como los que se hallan en esta línea, el espejo de la memoria recuperada por un hablante poético que, como en el caso de Vega, utiliza nombres propios que refuerzan

55 La legendaria historia de los hermanos que se separan, la cruz que "muere" con la muerte del abuelo, el tío muerto que se aparece en los sueños de su hermana, por ejemplo. 
la lectura autobiográfica. A diferencia de los anteriores, en los que el alejamiento del espacio familiar recuperado implica la distancia y la necesidad de remontarse a un pasado remoto y casi mítico, en el caso de este libro la continuidad es mayor: infancia, adolescencia, juventud. El quiebre más bien es anunciado por el final del conjunto: la adultez, la cancelación de una etapa cuya memoria es imprescindible para continuar el camino de la vida. Es por ello, quizás, que (Nadie se mueva) se inscribe en un universo más cotidiano, sin por ello ser trivial: la voz que habla en el libro, en un tono narrativo y no pocas veces reflexivo, sabe calibrar bien la emoción; sin excesos ni fáciles recursos, con sencillez y profundidad.

Dos libros que completan las menciones son El secreto de los sachapuyos (1994) de Sonaly Tuesta, en que se reconstruye la historia familiar en un tránsito que va del Chachapoyas natal ${ }^{56}$ (anticipada por viñetas que se remontan algunos cientos de años: a los sachapuyos) hasta Lima, destino de la migración de la hablante y su familia ${ }^{57}$, y Ritual de los prójimos (1999) de Renato Cisneros (libro que transita entre la línea culturalista y este "espacio"), en que la reconstrucción de la infancia de barrio (los amigos) y el espacio familiar (sobre todo las imágenes del padre muerto) le devuelven al sujeto poético su propia imagen: en ellos se mira y se descubre.

f) Una línea que cuenta con varios representantes en los noventa es la que propone el poema como espacio de ritualización. En líneas generales, el texto es el lugar en el que se construye y se celebra el mito ahí creado. La palabra apunta a recuperar su dimensión sagrada, personal o colectiva, y busca ser rito u oración. No porque se establezca necesariamente una conjunción poesía-vida que le dé a los textos un carácter místico que excede el texto del poema, sino porque así se organiza el proyecto literario. En general, además, los libros que

56 La Amazonia ya había sido, en 1991, motivo de un trabajo que podría inscribirse también en esta línea, de no ser porque la autora, Ana Varela Tafur, escapa de los márgenes que definen al grupo de poetas de los noventa: Lo que no veo en visiones. Lima: Editorial Copé, 1991.

57 La vida del migrante en una ciudad que resulta cruelmente nueva fue abordada (luego de los poetas del setenta) por Pedro Escribano en su importante Manuscrito del viento. (Lima: Lluvia Editores, 1982). 
caen en esta línea se proponen como organizaciones cerradas y no como conjuntos de poemas alrededor de un eje. Lo planteado podría hacer pensar en un lenguaje que rehúye de los hallazgos de la modernización poética de Hispanoamérica de los sesenta y mira hacia atrás; es cierto que no se trata de una apuesta coloquialista o conversacional (más bien se apuesta por un verso oscuro, cargado de símbolos, que evita sumergirse en lo cotidiano), pero no se desconocen los aportes de cierto tono eliotiano o Hinostroza, por citar un par de nombres afines al proceso mencionado; ni se niega el uso, eventualmente, de coloquialismos. Además de las fuentes clásicas, los textos sagrados, las referencias orientales, Saint-John Perse, Blake, Eielson, entre los más reconocibles. Los ámbitos temáticos pueden ser diversos: el amor y la celebración erótica de los cuerpos, la devoción a las divinidades de la oscuridad, los tránsitos hacia el espacio de la muerte, la celebración del sacrificio de los cuerpos o el descubrimiento en ellos del ser más esencial, el ritual de las palabras...; pero -y a pesar de las características que distinguen cada voz- une a estos libros su voluntad de devolver a los espacios poéticos la sensación de trascendencia o permitirles tocar las fibras de lo misterioso. Esto es lo que se puede observar en textos como De las causas y los principios. Venenos/embelesos (1992) de Grecia Cáceres Figueroa (1998), Acto primero de Carlos Arámbulo, En los sótanos del crepúsculo de Héctor Ñaupari, Inmanencia (1998) y Regreso a Ourobórea (1999) del grupo Inmanencia, Beissán o el abismo (1996) de Lorenzo Helguero, Bajo el cielo de Satán (2000) de Enrique Hulerig, Ojo madre (2000) de Antonio Sarmiento, Bestia escrita (2000) de Ricardo Ayllón, El grito (2001) de Carlos Villacorta o mi Ritos funerarios (1998). También en alguna medida Ritual del silencio (1995) de Camilo Fernández Cozman, Ello (1996) de Gabriel Espinoza, Por la identidad de las imágenes (1996) de Leoncio Luque, Almacén de invierno (1996) de Ayllón, Diotima de Mantinea (1997) de Andrés Piñeiro, Final aún (2000) de Edgar Saavedra o mi Rincones (Anatomía del tormento) (1991).

Un libro que parcialmente se acomoda a esta línea y que por sus particularidades en la poesía reciente vale la pena mencionar en este aparte es Libro del Sol (2000) de Josemári Recalde. La voluntad de celebración ritual de los poemas es clara; pero ésta no se ubica en el ámbito de la oscuridad, como la mayor parte de los anteriores, sino más bien de la plenitud de la luz que supone el descubrimiento de la iluminación de Dios a través de ritos que remiten a la fe cristiana 
y la tradición de chamanismo (en una convicción mística que en su caso trasciende los poemas), y está en diálogo pleno con los espacios cotidianos (ciertos barrios y calles, la naturaleza de los parques, la casa familiar). Todo esto con un lenguaje que combina cultismos con expresiones coloquiales, y que revela un consciente y coherente manejo de fuentes en función de una voz propia e intransferible:

Correo intercelestial

¿Dónde estás?, padre mío

¿En el recodo de qué tristeza recogeré tu mirada?

¿Hace cuánto que tú y yo estamos solos?

Tú en tu mundo de allá, sinigual.

Yo, en el permeado de acá.

Hoy que T. se casa y yo no fui a su boda

porque no lo veo desde los 10 u 11 años, ¿sabes?

¿Por qué me has dejado?

Hoy tengo 25 años.

Y estoy solo.

-¿Por qué andas así pregonando? -me respondiste, alma.

¿Sabes que conocí la anteiglesia de donde es originario mi abuelo, allá en Vizcaya?

Hablé unos minutos con la tía Cándida, y fui luego al Ateneo de Valmaseda.

Allí escuché a txistularis

y a "Izekariak" tocar el txalaparta,

participé en el ritual de despedida

y nos hicimos amigos con un vasco.

Hoy estoy de nuevo en "Elia",

la antigua bodega de Magdalena del Mar,

mi ciudad natal,

esperando, otra vez, una postal.

Cerca de la propuesta de Recalde, José Pancorvo -que, aunque por edad podría asociarse a la promoción surgida en los setenta, apareció en la escena literaria en los noventa y vinculado a los poetas jóvenes de esta hornada-, presenta, en sus libros Profeta el Cielo (1997) y Tratados omnipresentes/Perfect windows (2000), una poesía que podemos 
llamar mística e incluso mesiánica. Ricardo González Vigil hace una buena presentación de su propuesta:

Subrayemos la densidad simbólica y la riqueza de referentes culturales: el legado bíblico, cimas de la mística y la teología (los Padres y Doctores de la Iglesia), surtidores milenarios que Pancorvo enlaza con el mundo contemporáneo y el contexto nacional, asumiendo el sincretismo religioso, el milenarismo del mito del Incarrey, los danzantes de tijeras, el culto de santa Rosa de Lima y la 'travesía de extramares' de Martín Adán. Dicho enlace entre lo antiguo y lo moderno, lo 'occidental' y lo 'andino' se hace patente, también en la convivencia de composiciones con metro y rima (privilegiando el soneto) junto a textos en verso libre y exploraciones de la 'poesía visual'. De otro lado, el discurso en español admite versos, cuando no poemas enteros, en otros idiomas: latín, portugués, quechua y aimara" ${ }^{\prime \prime 5}$.

Un tercer ámbito dentro de este "espacio" supone la ritualización de la propia palabra poética. Aquí, los poetas, más allá de plantear la eventual escritura de artes poéticas, han planteado como eje organizador de sus trabajos la celebración del verbo y el develamiento de sus misterios. El lenguaje utilizado es parco, meditado; todo exceso -parece plantearse en esta concepción de la poesía- puede arruinar el poema. Lo narrativo se deja de lado: no interesa contar, sino aprehender, contemplar; el silencio, entonces, se propone imprescindible. Con una mano en la garganta (1996), segundo libro de Luis Fernando Jara da cuenta de estas reflexiones. Para Jara, de algún modo continuando lo que se observaba en su primer libro, Eroscopio (1990), la pasión por la palabra es indesligable de la pasión del amor: en Con una mano en la garganta se sostiene que si falta la mujer, la palabra deja de existir o hace más difícil su presencia. Es así como uno de los sentidos del título se hace patente: la angustia de lo inefable. El otro, que remite a la sensación que hacen las palabras al salir, es decir, acercarse al misterio de la voz, es el que más presente está en el libro ${ }^{59}$.

En El libro de los lugares vacíos (1999), de José Gabriel Cabrera Alva, la palabra es celebrada oblicuamente. Casi sin darnos cuenta leemos que iniciarse en la poesía es aprender a contemplar los espacios

58 Ricardo González Vigil. Op. cit., p. 545.

59 Es posible ubicar Lo torpe (2001) de Roberto Zariquiey cerca de esta propuesta. 
vacíos, aquéllos en donde están las esencias de las cosas. De ahí surge la posibilidad de leer el libro como el testimonio del aprendizaje (y la invitación a los lectores) de la actitud que se propone necesaria para el poeta bajo esta concepción de poesía: la callada observación, la disposición a ser sorprendido por una repentina iluminación que, como corresponde a la lección oriental que habita en el poemario, la hallaremos en la naturaleza, en lo cotidiano, en uno mismo: en el silencio que es de donde emergen las palabras.

Miguel Ildefonso, en las secciones "Envíos/Extravíos" y "La palabra volada de la sien", segunda y tercera de Vestigios (1999), su primer libro, plasma la intensa búsqueda de la palabra que ha dejado sólo sus vestigios; el poeta es el llamado -conforme sugiere la intensa metatextualidad de los poemas- a reunirlos y a reconstruir el verbo perdido.

g) Aunque no se trata aún de una línea suficientemente consolidada, hay algunos poetas que, situándose diametralmente al frente del impulso coloquialista y antipoético que cuajó en las décadas anteriores, apuestan por un lirismo extremo, cuya palabra procura alejarse de la experiencia concreta, desrealizándola, para fundar un espacio casi etéreo, hecho de puras sensaciones. Sahari (1997), primer libro de Bili Sánchez, apuntaba ya en esa dirección: la voz de un hombre a su hijo o a su infancia, a quien muestra un pasaje por recorrer (o recorrido): paisajes hechos de viento, sombras, cielo, agua, sueños, que actuaban como eco del ánima del hablante, en donde hay que hurgar. El segundo libro, Isa (2000), desde el discurso de un hombre enamorado que describe a su mujer, retoma los mismos principios y profundiza en la desrealización: el cuerpo de la amada, cierto que carne y tierra, es fundamentalmente presentido: su contemplación deviene en devoción que alimenta el mundo sensitivo de esa voz, ya de por sí desrealizada ${ }^{60}$.

Distinto es el registro de Campo traviesa (2000) de Francisco Jurado, aunque también dentro de la línea mencionada. En su caso se puede percibir una historia (la muerte de un individuo) en la que circulan personajes, que son más bien sólo voces que se encuentran. El hermetismo de las imágenes (en un lenguaje que combina extrañas

60 Muy cerca de ese universo de sensaciones está Estrella doble (2000), de Alejandra del Valle. 
adjetivaciones, coloquialismos, fragmentación del habla, erratas voluntarias, vuelos líricos) no permite asir la trama que se construye; pero deja, sí, una sensación en el lector de que algo veloz y casi irreal se desenvuelve ante nuestros ojos.

h) Un nuevo "espacio" -no con demasiados representantes, pero sí con una solidez que obliga a prestar una detenida atención- está marcado por una escritura que expresa una voluntad de construcción arquitectónica que diseña un recorrido (extensos conjuntos en que cada uno de los textos es en realidad un paso o una estancia en el trayecto que es el libro: un único poema), y un lenguaje que tiende al barroquismo por su recargamiento y los diversos registros que articula (culto, coloquial, técnico, lírico, antipoético, etc.). Los trabajos que se ubican en esta línea bordean, por lo anterior, el hermetismo y postulan un tipo de lector que esté decidido no tanto a una lectura placentera, sino, más bien, a una ardua aventura de indagación existencial.

Alberto Valdivia publicó en el 2000 Patología y La región humana; a pesar de su estructura diferente (el primero es una especie de diario de una voz que representa un cuerpo enfermo que se hurga y que se duele, y el segundo un extenso poema en partes que procura indagar en la esencia de la condición humana, también a partir del cuerpo) comparten un lenguaje marcado por neologismos y riguroso vocabulario técnico (médico, filosófico...). Si el primer libro se lee con mayor facilidad, gracias al relato que lo organiza; el segundo, cuyo abigarramiento y densidad resultan perturbadores -tanto por el manejo de referencias religiosas y filosóficas, como por la profundidad de su inmersión en el ser de la existencia (que nos enfrenta con un juego de multiplicaciones asfixiantes sobre los fragmentos de un espejo del hombre)- asume definitivamente el riesgo de la incomunicación: leer el libro puede ser -así lo ha querido el autor- una aventura trunca o abortada:

HEMOS pernoctado. En plural

(Padre y Pequeño / Icono de Carne y Hueso ante el Antropomorfo Encarnado Óseo

Tumba y Mortaja Lumbrera / Trayecto indeleble sobre la Huella Última) en consecuencia de la nueva disciplina promulgado el desvarío ejercicio-negación de fe abierta está la espera a (no) concluir en tu recurrencia 
en el ligamento prometido / pacto incólume / tu rúbrica analizable a destajo por terapias falibles a mis patologías Alucinación y Delirio encima catatónico esos dioses decantados para ser sustituibles en este límite me desplazan el dictaminador Fármaco / agnostizándome laico de su iglesia / me desplaza

Testigo de la Asolación como fe.

Debo negarme a esa creencia carente ejercer con prudencia la ceremonia sensorial / sin curtir pieles inflamables separar la paja de la ceniza consagrar la Zarza Verdad no revelada / tú Verdad por revelar en cada manchón de mis dedos chamuscados no brasa / no cuerpo incinerado dios en cada combustión atómica ese humo fatuo.

El mito zodíaco de la noche testificable el astro venido a menos sobre mi línea de limitación o su rompimiento no ha sido proyección mortal de ambivalencias morales ni qué decir necrofilia en autobúsqueda truncada. Este acto se inmola notificación pasar la noche juntos certifica siempre una relación prometedora todo rito conjunto / además si cotidiano / evidencia un grado

mayor de mestizaje

Acto legalizable y premonición de estadía (imposible aún determinar tiempo / alcance y condición) como ente ubicuo tus aproximaciones suelen ser truculentas o trucadas pero casi siempre comprobables ${ }^{61}$.

También los libros de Rafael Espinosa -Reclamo a la poesía (1996), Fin (1997) y Geometría (1998) - expresan la voluntad de una construcción rigurosamente compacta, sobre todo Fin -que traza una "marcha de Javier Heraud 118 a la Huaca Juliana" (como reza el subtítulo),

61 Tomado de la sección 4, "Territorio de regencias". 
en que la búsqueda de la utopía (representada por el viaje hacia el recinto sagrado y por qué no, por la dirección planteada como punto de partida) permite un recorrido por diversos espacios de una ciudad plural (marcados en su diferencia por las varias modulaciones de la voz del "peregrino") que son al mismo tiempo estancias del ser- y Geometría, en donde el discurso continuo y aparentemente frío (tercer hito en una ruta de hermetismo ascendente) indaga en los tópicos de la poesía, la muerte y el amor, desde una voz reflexiva casi monotonal, aunque híbrida.

Gonzalo Portals, finalmente, aunque con un hermetismo menor que sus compañeros de "espacio", es el que más expresamente ha trabajado el concepto de viaje o recorrido en sus poemarios (Piedecuesta (1993), Confirmaciones de un descreído (1995), Casa de tablas (1997), Itinerario del cuerpo (1998) e Histología (2000), otorgando con ello un componente narrativo a sus conjuntos. De este modo, los diversos temas tocados (el amor, lo trascendente, el cuerpo, la existencia humana, la ciudad) se abordan desde estados anímicos o emocionales, así como de posturas ante la vida, distintos.

i) Un último "espacio" para la comprensión de la poesía de los noventa está caracterizado por la vocación de libertad total de la palabra. Cierto ánimo vanguardista y experimental nutre la escritura de los libros que se ubican en esta línea, en los que la palabra parece desbordarse gracias a una corriente de fuerza arrolladora. Se observa también un hermetismo, en este caso de las imágenes que limitan sus posibilidades referenciales: aquí al lector -a diferencia del "espacio" anterior, que planteaba una gran participación de la razón- se le exige dejarse llevar por la sensorialidad y el flujo de las imágenes.

En el caso de Johnny Barbieri (fundador de Noble Katerva), se nota, además, una fuerte marca beatnik, modulada a través del magisterio de Enrique Verástegui, notorio en Branda y la mesón de los pandos (1993) y sobre todo en El libro azul (1996). En ellos, erotismo, deseo, sueños, libertad, proyección hacia lo trascendente, indagación en lo subconsciente, aparecen en un desbordado recorrido que se acerca a los impulsos de la escritura automática. Maka (1999), su tercer libro, mantiene temas, personajes e imaginería surrealista; pero introduce una mirada que desconfía de las posibilidades del encendido verbo creador de mundos ("En vano la vida ha transcurrido como la habíamos 
imaginado"), que ahora se revela sólo como escritura, "papeles / que perfectamente voy guardando / en mis cajones para siempre").

También se inscriben en esta línea (a pesar de lo distinto de sus propuestas) Roberto Sánchez Piérola, con Alleinlandlied (desde el escenario) y Ego puto (ambos de 1999), Rubén Quiroz, autor de Imago mundi (2000) y Niño vudú (2001), Alfredo Román Loayza con El valle (2000) y Antonio de Saavedra, mentor del grupo neosurrealista, con Laguna de electricidad (1998) ${ }^{62}$.

Las anteriores son las líneas más evidentes de la poesía de los noventa. Varias de ellas podrían aproximarse entre sí para formar ejes mayores, que se reconocerían, en términos amplios, como un registro coloquial o narrativo conversacional, frente a un espacio de mayor desarrollo de lo lírico o a una vocación más experimental. Organizar así el universo de los noventa, sin embargo, como anoté, impediría apreciar en su real magnitud la dinámica rica y compleja de la poesía joven de estos años. La revisión hecha, por el contrario (aunque pueda corregirse en algunos de sus términos, como es obvio), resulta más útil, creo, para vislumbrar un panorama más completo de lo que está ocurriendo. No obstante, las líneas planteadas hasta aquí no agotan todas las posibilidades en las que se mueve la poesía peruana de los años noventa.

No he mencionado, por ejemplo, lo que concierne al sujeto poético femenino que, luego de su efervescencia en los ochenta, pareciera haberse retraído, y disminuido los discursos que reivindican su diferencia. Sin embargo, con relación a la escritura de las mujeres, el panorama es, de hecho, bastante más complejo y, nuevamente, se evidencia una realidad que en los años ochenta no se alcanzó a clarificar: en dicha década se usó hasta la saciedad el cliché de la "poesía erótica femenina", con el que se colocaban en un mismo cajón voces, que si bien irrumpieron con fuerza colectiva en un mismo instante (nunca como en ese momento tantas poetas habían hecho sentir su

62 Aunque en este último caso, contra lo que caracteriza a este "espacio" y quizás por la ortodoxia asumida, los poemas se perciben poco intensos: la parafernalia surrealista está allí, pero no la libertad y la fuerza pasional que se podría esperar. 
presencia simultánea en el parnaso criollo), suponían claramente propuestas individuales. Es cierto que hubo un afán reivindicativo de la particularidad de la voz de la mujer en la poesía y una recurrencia temática del cuerpo y la sexualidad; pero desde registros más diversos de lo que se suele señalar y que, además, no fue general. En los años noventa ha quedado claro que el hecho de ser mujer y escribir desde esa posición, si bien puede suponer marcas textuales particulares ${ }^{63}$ (una discusión pendiente y que, al parecer, todavía no puede darse sin que entren en juego prejuicios y descalificaciones), ello no construye de por sí una línea poética. Así, varias de las poetas más interesantes (Montserrat Álvarez, Roxana Crisólogo, Victoria Guerrero, Sonaly Tuesta, por ejemplo) han inscrito sus trabajos en algunas de las líneas mencionadas en las páginas anteriores, ya sea desde un sujeto femenino o, en el otro extremo, ocultando las huellas gramaticales de la voz de mujer. Entre las que mantienen el interés por la voz de mujer (Violeta Barrientos, Grecia Cáceres, Ericka Ghersi, Themis Castellanos, Jeamel Flores, Josefina Barrón, Jessica Morales) el tema de la mujer en la sociedad, la familia, la pareja o la historia no es único (no lo fue antes tampoco) y las modalidades de escritura oscilan entre lo coloquial, lo lírico, lo celebratorio, etc. Es decir, la escritura de mujer es, como la de sus pares masculinos, lo suficientemente diversa como para arriesgarse a postular una línea que las reúna.

Tampoco he anotado la aparición -aún discreta, es cierto- de un sujeto poético de opción homosexual (como aparece en El libro de las señales de Yrigoyen o en El innombrable cuerpo del deseo (1992) de Violeta Barrientos) ni la apuesta por poetizar desde el cuerpo y su visceralidad, paradójicamente más vinculada en los años noventa a los poetas hombres -como en Patología o La región humana de Alberto Valdivia, Itinerario del cuerpo de Portals, El grito de Villacorta o mi

63 Véanse, al respecto, los fundamentales aportes de Rocío Silva Santisteban (por ejemplo "Basta ser mujer para escribir como mujer", en El combate de los ángeles. Literatural género/ diferencia. Lima: Pontificia Universidad Católica del Perú, 1999, libro colectivo compilado por ella) o de Susana Reisz (sobre todo Voces sexuadas. Género y poesía en Hispanoamérica. Lérida: Asociación Española de Estudios Literarios Hispanoamericanos, 1996). 
Rincones (Anatomía del tormento) ${ }^{64}$ - que al discurso reivindicativo de la poesía escrita por mujeres, por razones similares.

Queda para el final la mención de dos poetas que no encuentran lugar con facilidad en el recorrido planteado. Uno es César Gutiérrez en La caída del equilibrista (1997), donde, con títulos que remiten a la narrativa policial y escenarios de ciencia ficción poshistórica, los poemas combinan lirismo, estética del cómic y sensual tonalidad rockera, apuntando a la renovación de la poesía a través de la incorporación de los discursos de estas artes finiseculares ${ }^{65}$, cuyo impacto en la vida cotidiana de los jóvenes (cuando menos) es innegable. El otro es Lorenzo Helguero, quien desde que con Sapiente lengua se propuso desafiar el canon establecido y optó, a total contracorriente, por la escritura de sonetos, no ha dejado de sorprender por sus constantes cambios de registro (incluso se ha comparado su actitud con la del portugués Pessoa ${ }^{66}$ ): el humor vanguardista y desfachatado de las prosas de Boletos (1993), la oscuridad de Beissán o el abismo, el irónico y desmitificante vistazo al amor revisitado en "Shame Dean" (1999) y las lúdicas viñetas de El amor en los tiempos del cole (2000). Oculta, así, su verdadera voz, o demuestra, quizás, que el yo unidimensional es sólo una construcción engañosa, más aun en tiempos como éstos.

Para cerrar este acápite es pertinente plantear algunas interrogantes sobre la relación entre los "espacios" propuestos y la institucionalidad literaria. Si volvemos la mirada, por ejemplo, a la conciencia de la exclusión (y la voluntaria aceptación de ésta) que, en términos generales, se manifiesta en los sujetos poéticos del malditismo, cabe preguntarse si la voz que habla en el texto es sólo un constructo ficcional o la marginalidad que anuncian los poemas es, más bien, una toma de posición del poeta frente a la oficialidad literaria e incluso la sociedad en su conjunto. ¿O, quizá, la asunción de una postura epatante, porque epatar da réditos indiscutibles? Algo semejante quedó señalado con relación a la dicción conversacional

64 Y los Estudios sobre un cuerpo (Lima: Colmillo Blanco, 1991), de Jorge Frisancho, aunque a este poeta, como señalé, se le ubica en los ochenta.

65 En la línea de las exploraciones de Oswaldo Chanove, desde los ochenta.

66 Véase González Vigil, Ricardo. Op. cit., p. 743. 
culturalista: asumirla en alguna medida -esto era claro en los años ochenta y aun a inicios de los noventa- era situarse en un espacio institucionalmente privilegiado y aseguraba al menos (bajo el supuesto de una cabal plasmación de los proyectos) una respetuosa mirada. ¿Esto decidió a algunos poetas? El coloquialismo, por su parte, además de plantear una lengua más próxima a la norma cotidiana, suponía todavía a inicios de la década que nos interesa un cuestionamiento del "buen escribir". Y podríamos seguir con la vocación trascendente de la ritualización o con la negación de un lector cómodo, etc.

Las preguntas no son nuevas, sin duda; pero plantearlas (y dejarlas así, a espera de una discusión que busque llegar a respuestas) permite no dejar de atender el proceso de los años noventa (la validación de diversos "lugares" de escritura -según la noción de "lugar" que postula Jenaro Talens ${ }^{67}-$ ), también desde una perspectiva política (de política interna, podríamos decir, o sea del juego de posiciones dentro de la oficialidad literaria). Terrenos delicados, por cierto, pero contribuirían a comprender mejor el funcionamiento de la literatura y los procesos poéticos.

\section{Cinco}

Se sabe que ni la literatura, en general, ni la poesía, específicamente, son reflejo automático de la realidad; que los textos literarios no son reproducción no mediada de la experiencia, sino creación de un mundo propio e inédito. Sin embargo, "la obra literaria es una entidad autónoma (que no es lo mismo que autárquica) que mantiene relaciones multidireccionales con otras instancias de la praxis ${ }^{\prime \prime 68}$ que, de muy diversas maneras pueden plasmarse en ellas y en el devenir de la situación y de la concepción del escritor.

67 "La individualidad que parece asumir [la voz de la escritura] no es un sujeto sino un lugar, algo que expone la huella de un cruce de convenciones sociales y discursivas explicitadas como tales". Citado en Laura Scarano. Op. cit., p. 15.

68 García Bedoya, Carlos. Para una periodización de la literatura peruana. Lima: Latinoamericana Editores, 1990, p. 28. 
¿De qué manera lo ocurrido en la década de los noventa dialogó con los textos escritos por los jóvenes poetas, con su comprensión de la poesía y de la institución literaria o con su ubicación en ella? Un breve registro de algunos de los hechos que en esta crítica década marcaron las preocupaciones del peruano común y la producción de la cultura, y de aquello que modificó el rostro del mundo, nos puede brindar algunas pistas.

Los años noventa, como años de desencanto, de cínica lucidez, de escepticismo, estuvieron, sin duda, condicionados por la caída del muro del Berlín (que, de algún modo, dio inicio al siglo XXI). Con el muro, cuyo derrumbe significó una fiesta democrática, cayeron también, sin embargo, los restos de utopías e ideales que sobrevivían desde las generaciones anteriores; cayó también buena parte del sentido político de los individuos y se instauró (al menos en alguna medida) la lógica del fin de la historia y de la imposible superación "del horizonte material y cultural de la modernidad burguesa" ${ }^{\prime 69}$ : salvo el libre mercado todo era ilusión. La globalización y su contraparte, la exclusión -la institucionalización de los "prescindibles"- son parte de este proceso.

En países como el Perú, donde pronosticar el fin de la historia suena poco menos que a ciencia ficción, los coletazos del mundo posmuro de Berlín se hicieron escuchar, sin embargo, con gran volumen, por la bancarrota del Estado alanista y la improbable solución, al iniciar la década, de la guerra interna que enlutaba al país. Todo esto se tradujo en el quiebre del sistema partidario (las votaciones de los "independientes" Belmont - para la alcaldía de Lima en 1989- y Fujimori -en las presidenciales de 1990- son hitos indiscutibles) y en el desprestigio -real, pero además promovido- de la llamada "política tradicional". Luego vino la imposición de una versión "chicha" del neoliberalismo y la gradual ruptura de la institucionalidad ${ }^{70}$.

Con Fujimori llegó también el "orden". La estabilización de la economía y la derrota del senderismo en 1992, luego de los años más duros que Lima recuerda (apagones, coches bomba, los experimentos

69 Ballón, José Carlos. “Modernidad cultural, capitalismo y socialismo. ¿Han cambiado realmente los términos del debate?". Márgenes 12, p. 169.

70 "La década de la antipolítica", ha llamado a ésta Carlos Iván Degregori, en su reciente libro: La década de la antipolítica. Auge y huida de Alberto Fujimori y 
de la sociedad senderista en Raucana, la destrucción de la comisaría de Villa El Salvador y la calle Tarata en Miraflores ${ }^{71}$ ), devolvieron a la ciudadanía cierta tranquilidad que, de paso, reforzó el sentido común que ofrecían los nuevos tiempos: inutilidad de las organizaciones políticas, pragmatismo y mano dura.

La "tranquilidad", empero, tuvo un costo que pocas veces se recordaba antes de estos recientes tiempos de colapso y fin del período fujimorista: las violaciones a los derechos humanos, la destrucción de la institucionalidad democrática, los mecanismos de copamiento del poder y el aumento consecuente del autoritarismo. También la economía estabilizada, que resultó ser congelamiento económico: empobrecimiento, retracción de la producción, subempleo generalizado, caída inédita de las clases medias... y, ya innegable en los últimos meses, la corrupción más espantosa en todo el período republicano peruano. Algunos de los dolorosos símbolos del modelo "fujimontesinista" son el autogolpe de 1992, las matanzas de Barrios Altos y La Cantuta, la tortura de Leonor La Rosa, y, mucho más cerca, la explosión provocada por el propio régimen en el Banco de la Nación, el video Kouri-Montesinos, primero de una larga serie, y la renuncia de Fujimori desde el Japón. Todo lo mencionado, paradójicamente, en un escenario que promueve las ilusiones de la globalización (internet, cable, sociedad de la información) y la modernización. Probablemente se trata de una de las décadas más difíciles y traumáticas para la historia del siglo XX peruano ${ }^{72}$.

Vladimiro Montesinos. Lima: IEP, 2000. Es claro que la referida es, básicamente, antipolítica partidaria; el neoliberalismo preconizado tras la crítica a la "política tradicional" no deja de ser discurso y práctica política. Aunque ya no corresponde al contexto de la poesía de los noventa, se puede apuntar que el escenario reciente parece reiniciar algo semejante a un nuevo ciclo partidario.

71 Nunca como en los años 1990-1992, Lima sintió tan cerca el miedo de un posible triunfo de Abimael Guzmán y sus huestes sobre el Estado peruano.

72 Aunque esto es relativo y más de una vez se dijo en años anteriores: "En la memoria de los peruanos el año 1983 quedará como uno de los más trágicos, desde cualquier punto de vista que no sea el del ministro de Economía", para citar una muestra tomada de un texto de crítica literaria (O’Hara, Edgar. "Sujeciones y avances en el lenguaje poético de la poesía joven peruana". Revista de Crítica Literaria Latinoamericana 20. Segundo semestre de 1984, p. 233). 
¿Qué diálogo se estableció entre poesía y sociedad? Algunas evidencias de éste son patentes en los "espacios" de marcada vocación "realista" (el malditismo, la representación del espacio suburbano). También un síntoma de este diálogo es la recurrencia de lo íntimo, lo trascendente y lo desrealizado. Un ejemplo más dramático $-\mathrm{y}$ más interesante, por lo polémico que podría resultar- es el voluntario camino de exclusión, trazado por la poesía de los años noventa, de toda referencia directa a la violencia política del período 1980$1992^{73}$ que fue, sin dudarlo, aunque no necesariamente contacto de primera mano, sí alimento constante del estado de ánimo y de la percepción del país de los jóvenes poetas (por lo menos los nacidos hasta 1975). Camino que fue continuado, como es previsible en ellos, por los menores, cuya aproximación fue más un recuerdo ajeno que experiencia propia. Salvo algunas excepciones, mínimas en realidad considerando el volumen del corpus de la poesía de estos años, la guerra interna es un tema inexistente ${ }^{74}$. Quizá lo más próximo a la representación de la violencia vivida esté en el lado de la poesía que, a inicios de la década, construyó sus escenarios como testimonio de la degradación en una urbe caótica y enferma; sin embargo, estos textos son, a veces, más deudores de la retórica de la malditez urbana, que de un procesamiento efectivo de la experiencia de esos años. Con esto no se quiere apuntar a una obligación incumplida por la poesía de los años noventa, sino dejar constancia de un espacio sintomáticamente vacío (y la ausencia es, bien lo sabemos, una forma contundente de presencia) en el juego de representaciones que es la literatura.

Queda la pregunta, entonces, de cómo la guerra interna empapó los ánimos de una promoción de poetas que participó, al menos -más o menos cerca, más o menos lejos- del embrollo subjetivo producido y cómo se trasluce eso en la poesía. La desazón y el escepticismo

73 No acabó, definitivamente, en ese año; pero sí se cerró una etapa con la captura de Abimael Guzmán.

74 Se pueden mencionar: un poema de Martín Rodríguez-Gaona ("La eternidad está enamorada de los frutos del tiempo" en Pista de Baile); algunos de Montserrat Álvarez ("Los relojes se han roto" o "Los que van a la guerra”, por ejemplo); el poema II de la sección "21 pepas de amor..." en 21 pepas de amor y una canción desentonada de Verónica Álvarez. 
reflejados en los textos, el regreso a la revisión de los conflictos de la intimidad y los quiebres internos (exilios interiores, podríamos decir, como único refugio frente a un mundo que se desmorona) o la recuperación poética de los espacios familiares, que se erigen como panteones privados que se contraponen a la percepción de lo colectivo nacional nos dan algunas pistas ${ }^{75}$, aunque, claro, no es posible querer explicar estos caminos sólo como reacciones a lo experimentado frente al espacio público. También se puede señalar que los poetas de los años noventa, al verse desbordados por acontecimientos como los de la violencia política, que exigían una distancia crítica mayor, pues superaban las posibilidades aún en formación de sus lenguajes, prefirieron evitarlos. O decir que la costumbre de la muerte produce corazas infranqueables, incluso en la más permeable subjetividad de los poetas. Otras interpretaciones apuntan a que los acontecimientos de la guerra que desangró al país pasaron lo suficientemente lejos de los poetas, que, en tal sentido, no se sintieron empujados a procesar desde sus textos lo vivido en otros ámbitos ${ }^{76}$, o a la postulación de un movimiento de retracción frente a la intensidad de un discurso que estuvo muy atento al espacio público y a las diversas violencias como escenario poético fundamental (y quizás aquí se encuentren, parcialmente, algunas de las explicaciones de la pérdida de la hegemonía de la poesía conversacional).

Como sea, hay un hecho que resulta simbólico de la actitud asumida: el recital del 17 de mayo de 1991, organizado por el grupo Neón en el contexto de la Semana Cultural Sanmarquina, que congregó a muchos de los jóvenes poetas que empezaban a aparecer. Mario Sifuentes, periodista de la sección juvenil de El Comercio, lo recuerda así:

... en el Pabellón de Letras siempre se realizó el recital con jóvenes poetas de La Cantuta, Garcilaso, San Martín, Católica, Lima y San Marcos. Perfomance irregular que no mejoró con la participación en música de Rafo Ráez y el grupo Virgen Sideral, así como del teatro de

75 Procesos semejantes se vivieron en la narrativa, la plástica y el rock, al menos hasta hace pocos años.

76 Esta hipótesis fue propuesta por Víctor Coral en una conversación reciente en la que participamos, además de Coral, Victoria Guerrero, Miguel Ildefonso, Diego Otero y yo. Véase revista Flecha en el azul 15, 2001, p. 56. 
Ulkadi. Promediando el recital acusó fuerte, afuera, una explosión. Nadie perdió el control ni hubo palabras tranquilizadoras; en el salón lleno todo siguió con normalidad. Una segunda explosión y luego varias más. Pocas personas fueron las que se pararon y yo salí con ellas... De vuelta, todos los pabellones, pasajes, cables y postes estaban metódicamente abanderados ${ }^{77}$.

Aunque son varias las lecturas posibles ${ }^{78}$, mi recuerdo de esa tarde no deja de lado la impresión de que poetas, músicos y público ("noventeros" casi en su totalidad) casi ni se inmutaron frente a lo que estaba ocurriendo. Es decir, pareció que no se inmutaban: "todo siguió con normalidad". Como en la poesía de los años noventa, en el recital la violencia pasó por el costado: nadie explicitó que estaba tomando nota de lo sucedido.

\section{Y seis}

La revisión hecha en las páginas anteriores permite cerrar este texto planteando una pregunta distinta a la propuesta al inicio: ¿cuál es la particularidad de la poesía de los años noventa? Sin duda, muchos de los rasgos y de los "espacios" que recorren los poetas de esta promoción no son nuevos (aunque sí hay varias ampliaciones de caminos conocidos a los que habrá que seguirles la pista); pero hay hoy la posibilidad de observar con más claridad lo que antes no era todavía nítido: ésta tal vez sea la mayor contribución de los años noventa, al margen del valor de los propios textos poéticos. Si hay alguna particularidad en el panorama global de esta poesía es que, al parecer, le ha tocado la feliz coincidencia de ser tiempo de convivencia plural (rollo posmoderno de por medio) y habitar el final del siglo y del milenio.

La poesía no cambia cada diez años; tampoco detiene su permanente movimiento. $Y$ los nuevos poetas, los que en los años noventa irrumpieron en la escena pública, han dado ya a nuestra tradición algunas voces importantes, además de las razones suficientes para

77 “Hacia la recuperación. A los 440 años de San Marcos". El Comercio. Domingo 26 de mayo de 1991, p. G-1 (subrayados míos).

78 Paolo de Lima, por ejemplo, me sugirió que explicite el propósito de decir que el recital se realizó a pesar de la presencia amenazante de Sendero. 
atender su presencia en la comprensión del proceso poético peruano del siglo XX y, quizás -el tiempo lo dirá-, del que se inicia. Es por eso que trazar un mapa de lo ocurrido es, no sólo importante, sino imprescindible. Pero no para crear un nuevo gueto que defender a rajatabla (al lado del propósito de brindar un panorama de los años noventa, animó este trabajo la paradójica pretensión de contribuir a desterrar un modo de organización de nuestra poesía que no favorece la comprensión cabal de los fenómenos poéticos), sino para ensayar nuevos modos de enfrentar nuestra tradición. Son innumerables las tareas que este segundo aspecto reclama y espero, al menos, haber podido apuntar algunas. Acerca del panorama de los años noventa, la discusión apenas se está abriendo ${ }^{79}$.

\section{El corpus: libros revisados de los poetas de los noventa}

Aguirre, L. (1999). La gruta del cangrejo. Lima: Nido de Cuervos.

Agurto, G. (1992). Comer carne humana. Lima: Ediciones de los Lunes.

Agurto, G. (1999). (Nadie se mueva). Lima: Vaca Flaca.

Álvarez, M. (1991). Zona Dark. Lima: Edición de la autora.

Álvarez Goyzueta, V. (1992). 21 pepas de amor y una canción desentonada. Lima: Los Sobrevivientes.

Arámbulo, C. (1999). Acto primero. Lima: Pathos.

Ayllón, R. (1996). Almacén de invierno. Chimbote: Lobo de Mar.

Ayllón, R. (1998). Des/nudos. Chimbote: Río Santa.

Ayllón, R. (2000). Bestia escrita. Lima: Fondo de Fuego.

Barbieri, J. (1993). Branda y la mesón de los pandos. Lima: Noble Katerva.

Barbieri, J. (1996). El libro azul. Lima: Noble Katerva.

Barbieri, J. (1999). Maka. Lima: Noble Katerva.

79 Como parte de esas discusiones, quiero dejar constancia de lo valiosos que fueron para mí los comentarios y observaciones de José Antonio Mazzotti, Rodrigo Quijano, Rocío Silva Santisteban, Alberto Valdivia y, particularmente, Paolo de Lima, a la primera versión de este trabajo. 
Barrientos, V. (1991). Elíxir. Lima: Noevas.

Barrientos, V. (1992). El innombrable cuerpo del deseo. Lima: Edición de la autora.

Barrientos, V. (1994). Tras la puerta falsa. Lima: Edición de la autora.

Barrón, J. (1994). Poemas son heridas. Lima: Colmillo Blanco.

Barrón, J. (1999). El ojo amurallado. Lima: Carpe Diem.

Bayly, D. (1996). Retrete para huérfanos. Filadelfia: Asaltoalcielo.

Bayly, D. (1998). Chico de mi barrio. Lima: Jaime Campodónico.

Beltrán Peña, J. (1995). Evangelio de la poesía. Lima: Gaviota Azul.

Beltrán Peña, J. (s/f.). Serpiente de Eva (un poema). Lima: Gaviota Azul.

Cabrera Alva, J. G. (1999). El libro de los lugares vacíos. Lima: Dedo Crítico.

Cáceres Figueroa, G. (1992) De las causas y los principios. Venenos/ embelesos. Lima: Edición de la autora.

Carnero, C. (2000). Las razones de los efectos. Lima: Gonzalo Pastor.

Castellanos, T. (1994). Las irrealidades perdidas. Lima: Pedernal.

Chicoma Lúcar, D. (1997). Mujer tras el espejo. Lima: Edición del autor.

Chueca, L F. (1991). Rincones (Anatomía del tormento). Lima: Colmillo Blanco.

Chueca, L F. (1996). Animales de la casa. Filadelfia: Asaltoalcielo.

Chueca, L F. (1998). Ritos funerarios. Lima: Colmillo Blanco.

Cisneros, R. (1999). Ritual de los prójimos. Lima: Universidad de Lima.

Coral, V. (2001). Luz de limbo. Lima: Delfín Arisco.

Crisólogo, R. (1999). Abajo, sobre el cielo. Lima: Nido de Cuervos.

Crisólogo, R. (2001). Animal del camino. Lima: El Santo Oficio.

Cruzado, L. (1996). Éste es mi cuerpo. Lima: Camión.

De Lima, P. (1995). Cansancio. Filadelfia: Asaltoalcielo.

DeLima, P.(1998). Cansancio. 2. ${ }^{a}$ edición. Lima:HispanoLatinoamericana. 
De Saavedra, A. (1995). Airones. Lima: Municipalidad de Lima.

De Saavedra, A. (1998). Laguna de electricidad. Lima: Caracol.

Del Valle, A. (2000). Estrella doble. Lima: Edición de la autora.

Del Valle, J. (1994) Callado cielo. Lima: Pedernal.

Durán, J. (1998). Festival de la desesperación. Lima: Mundo Sur.

Echarri, X. (1993). Las quebradas experiencias y otros poemas. Lima: Caracol.

Espinoza, R. (1996). Reclamo a la poesía. Lima: Mura.

Espinoza, R. (1997). Fin. Lima: Mura.

Espinoza, R. (1998). Geometría. Lima: Copé.

Espinoza Suárez, G. (1996). Ello. Lima: Ediciones del Coatí.

Espinoza Suárez, G. (1998). Ello. 2. ${ }^{\text {a }}$ edición. Lima: Dedo Crítico.

Fernández, C. O. (2000). Una vela encendida en el desierto. Lima: Derrama Magisterial.

Fernández Cozman, C. (1995). Ritual del silencio. Lima: Picaflor.

Flores, J. (1995). Desde los oscuros rincones. Lima: Colmillo Blanco.

Flores, J. (2000). Todo era lejos. Lima: Pontificia Universidad Católica del Perú.

Galdo, J. C. (1994). Si hubo algún lugar debió ser ése. Lima: Pedernal.

Galloso, J. A. (1998). Si huyes hacia adentro. Lima: Colmillo Blanco.

Gálvez, J. (1995). Libro de Daniel. Lima: Jaime Campodónico.

García Godos Salazar, R. (2000). No importa borrar. Lima: Lluvia.

Ghersi, E. (1994). Zenobia y el anciano. Lima: Arte Reda.

González Cueva, E. (1995). Intolerancia y otros poemas. Lima: Lluvia.

Guerrero, V. (1993). De este reino. Lima: Los Olivos.

Guerrero, V. (1996). Cisnes estrangulados. Lima: Cuernoenpanza.

Gutiérrez, C. (1997). La caída del equilibrista. Lima: El Santo Oficio.

Helguero, L. (1993). Sapiente lengua. Lima: Pedernal.

Helguero, L. (1993). Boletos. Lima: Pedernal. 
Helguero, L. (1996). Beisánn o el abismo. Lima: Ediciones de los Lunes.

Helguero, L. (1999). “Shame Dean”. Vórtice 5. Lima, junio.

Helguero, L. (2000). El amor en los tiempos del cole. Lima: Colmillo Blanco.

Hulerig, E. (2000). Bajo el cielo de Satán. Lima: Copé.

Ildefonso, M. (1999). Vestigios. Lima: Gonzalo Pastor.

Ildefonso, M. (2001). Canciones de un bar en la frontera. Lima: El Santo Oficio.

Inmanencia (Grupo). (1998). Inmanencia. Lima: Edición de los autores.

Inmanencia (Grupo). (1999). Regreso a Ourobórea. Lima: Edición de los autores.

Jara, L. F. (1990). Eroscopio. Lima: Jaime Campodónico.

Jara, L. F. (1996). Con una mano en la garganta. Lima: Arte/Reda.

Jurado Chueca, F. (2000). Campo traviesa. Lima: Edición del autor.

Luque, L. (1996). Por la identidad de las imágenes. Lima: Noble Katerva.

Morales, J. (1993). Piel de ceniza. Lima: Edición de la autora.

Olea, F. (1997). El perfume del camaleón. Lima: Colmillo Blanco.

Olea, F. (2000). Cajón desastre (primera prueba). Lima: Arlient.

Oliva, C. (1995). Lima o el largo camino de la desesperación. Lima: Hispano Latinoamericana.

Otero, D. (1998). Cinema fulgor. Lima: Colmillo Blanco.

Pacheco, C. (1997). Noche infiel. Lima: Deboleto.

Pancorvo, J. (1997). Profeta el Cielo. Lima: Alba.

Pancorvo, J. (2000). Tratados omnipresentes / Perfect windows. Lima: Gonzalo Pastor.

Piñeiro, A. (1997). Diotima de Mantinea. Lima: Dedo Crítico.

Polar, H. (1998). Poesía 1982-1998. Bogotá: Ritual de lo Habitual.

Portals Zubiate, G. (1993). Piedecuesta. Lima: Copé. 
Portals Zubiate, G. (1995). Confirmaciones de un descreído. Lima: Del Mar.

Portals Zubiate, G. (1997). Casa de tablas. Lima: Témpora.

Portals Zubiate, G. (1998). Itinerario del cuerpo. Lima: LB.

Portals Zubiate, G. (2000). Histología. Lima: Osis.

Quiroz, R. (2000). Imago mundi. Lima: Caparazón.

Quiroz, R. (2001). Niño vudú. Lima: San Marcos.

Rabí, A. (1992). Concierto en el subterráneo. Colección Homenaje al Centenario de César Vallejo. Trujillo.

Rabí, A. (1994). Quieto vaho sobre el espejo. Lima: Colmillo Blanco.

Rabí, A. (2000). En un purísimo ramaje de vacíos. Lima: El Caballo Rojo.

Rada, E. (1994). Geografía de un sueño. Lima: Los Sobrevivientes.

Ram del Pozo, O. (1991). Crónica de fundación. Lima: Sur de Lima.

Recalde, J. (1997). “Libro de Merlín”. Leteo 1. Lima, agosto.

Recalde, J. (2000). Libro del Sol. Lima: Flecha en el Azul-Ceapaz.

Rivas Tarazona, R. (s/f.). Milk the dance. Lima: Universidad Nacional Mayor de San Marcos.

Rivera, J. (2000). Fallas de origen. Lima: Tránsito.

Rivera, M. (1993). Hojas sueltas. Lima: Edición de la autora.

Rodríguez-Gaona, M. (1992). Efectos personales. Lima: Ediciones de los Lunes.

Rodríguez-Gaona, M. (1997). Pista de baile. Lima: El Santo Oficio.

Román Loayza, A. (2000). El valle. Lima: Universidad de Lima.

Saavedra, E. (2000). Final aún. Lima: Ediciones del Signo Lotófago.

Sánchez Montenegro, B. (s/f). Sahari. Lima: Escorpión Records.

Sánchez Montenegro, B. (2000). Isa. Lima: Edición del autor.

Sánchez Piérola, R. (1999). Alleinlandlied (desde el escenario)/Ego puto. Lima: Dedo Crítico. 
Sánchez Rivas, M. (1999). Entre la panza y el corazón. Lima: Officina Tipographica.

Sandoval Zapata, J. J. (1999). Lágrimas, poemario y otros graffitis. Lima: Jota.

Sarmiento, A. (2000). Ojo madre. Lima: Fondo de Fuego.

Segura, I. (1997). Bosque de formas. Lima: Nómadas.

Tuesta, S. (1994). El secreto de los sachapuyos. Lima: Los Olivos.

Valdivia Baselli, A. (2000). Patología. Lima: Osis.

Valdivia Baselli, A. (2000). La región humana. Lima: Fondo Editorial del Banco Central de Reserva.

Vega Jácome, S. (1995). Casa de familia. Lima: Los Olivos.

Velásquez Pomar, F. (1997). Pequeñas alegrías gramaticales. Lima: Abolida Siniestra.

Villacorta, C. (2001). El grito. Lima: La Cueva.

Ybarra, R. V. (1993). Sinfonía del kaos. Lima: Humo Bajo el Agua.

Ybarra, R. V. (1999). Vómitos. Lima: El Mantaro.

Yrigoyen, J. C. (1997). El libro de las moscas. Lima: Universidad de Lima.

Yrigoyen, J. C. (1999). El libro de las señales. Lima: Nido de Cuervos.

Zariquiey, R. (2001). Lo torpe. Lima: Edición del autor.

Zelada, L. (1993). Delirium tremens. Lima: Edigraf.

Zelada, L. (1997). Delirium tremens. Edición completa. Lima: Federación Gráfica del Perú. 